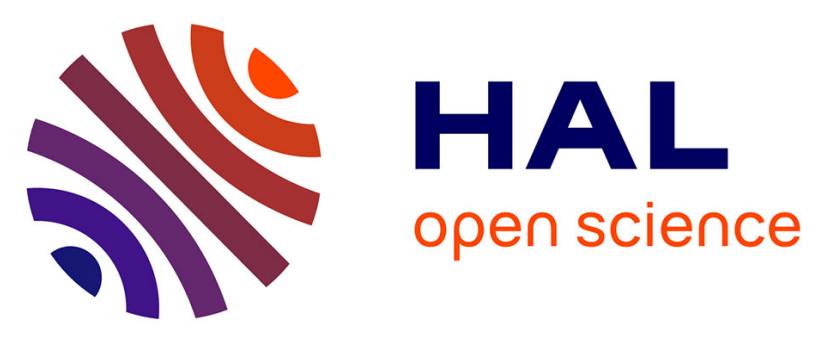

\title{
Deformation and sedimentary evolution of the Lake Albert Rift (Uganda, East African Rift System)
}

Brendan Simon, François Guillocheau, Cécile Robin, Olivier Dauteuil, Thierry

Nalpas, Martin Pickford, Brigitte Senut, Philippe Lays, Philippe Bourges, Martine Bez

\section{To cite this version:}

Brendan Simon, François Guillocheau, Cécile Robin, Olivier Dauteuil, Thierry Nalpas, et al.. Deformation and sedimentary evolution of the Lake Albert Rift (Uganda, East African Rift System). Marine and Petroleum Geology, 2017, 86, pp.17-37. 10.1016/j.marpetgeo.2017.05.006 . insu-01519685

\section{HAL Id: insu-01519685 \\ https://hal-insu.archives-ouvertes.fr/insu-01519685}

Submitted on 9 May 2017

HAL is a multi-disciplinary open access archive for the deposit and dissemination of scientific research documents, whether they are published or not. The documents may come from teaching and research institutions in France or abroad, or from public or private research centers.
L'archive ouverte pluridisciplinaire HAL, est destinée au dépôt et à la diffusion de documents scientifiques de niveau recherche, publiés ou non, émanant des établissements d'enseignement et de recherche français ou étrangers, des laboratoires publics ou privés. 


\section{Accepted Manuscript}

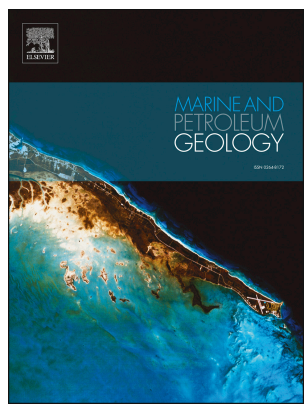

Deformation and sedimentary evolution of the Lake Albert Rift (Uganda, East African Rift System)

Brendan Simon, François Guillocheau, Cécile Robin, Olivier Dauteuil, Thierry Nalpas, Martin Pickford, Brigitte Senut, Philippe Lays, Philippe Bourges, Martine Bez

PII: S0264-8172(17)30166-6

DOI: 10.1016/j.marpetgeo.2017.05.006

Reference: JMPG 2898

To appear in: $\quad$ Marine and Petroleum Geology

Received Date: 19 November 2016

Revised Date: 29 March 2017

Accepted Date: 1 May 2017

Please cite this article as: Simon, B., Guillocheau, Franç., Robin, Cé., Dauteuil, O., Nalpas, T., Pickford, M., Senut, B., Lays, P., Bourges, P., Bez, M., Deformation and sedimentary evolution of the Lake Albert Rift (Uganda, East African Rift System), Marine and Petroleum Geology (2017), doi: 10.1016/ j.marpetgeo.2017.05.006.

This is a PDF file of an unedited manuscript that has been accepted for publication. As a service to our customers we are providing this early version of the manuscript. The manuscript will undergo copyediting, typesetting, and review of the resulting proof before it is published in its final form. Please note that during the production process errors may be discovered which could affect the content, and all legal disclaimers that apply to the journal pertain. 


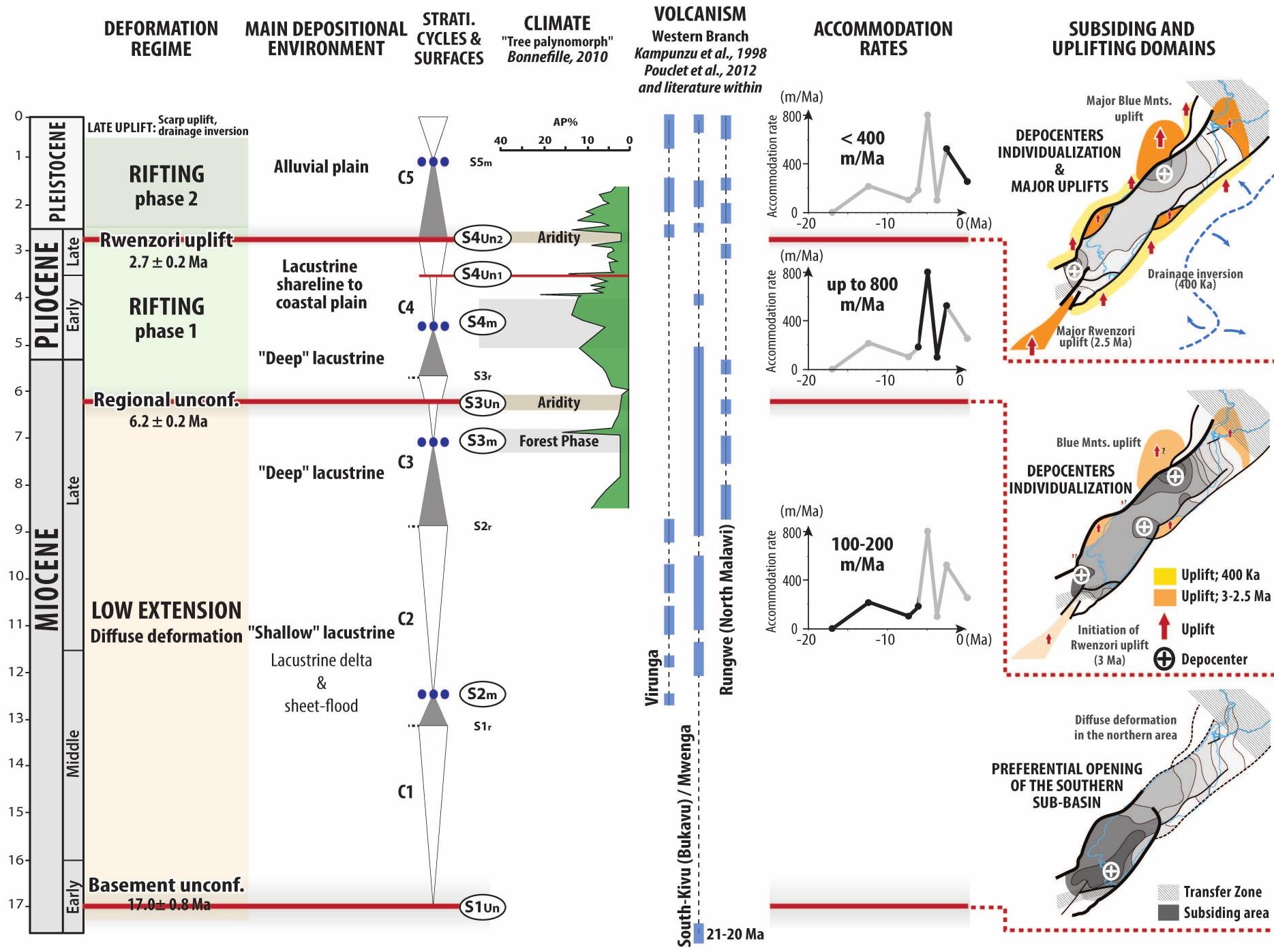


Deformation and sedimentary evolution of the Lake Albert Rift (Uganda, East African Rift System)

Brendan SIMON ${ }^{(1,2)}$, François GUILLOCHEAU ${ }^{(1)}$, Cécile ROBIN $^{(1)}$, Olivier DAUTEUIL ${ }^{(1)}$, Thierry NALPAS ${ }^{(1)}$, Martin PICKFORD ${ }^{(3)}$, Brigitte SENUT $^{(3)}$, Philippe LAYS ${ }^{(2)}$, Philippe BOURGES $^{(2)}$, Martine BEZ ${ }^{(2)}$

(1) Géosciences Rennes - UMR 6118, Campus de Beaulieu, Bât. 15, 263 av. du Général Leclerc, CS 74205, 35042 Rennes Cedex, France.

(2) TOTAL E\&P, CSTJF, Avenue Larribau, 64000 Pau, France.

(3) Muséum National d'Histoire Naturelle, UMR 7207, CNRS; 8 rue Buffon, CP 38, 75005 Paris, France.

Corresponding author: Brendan SIMON, simon.brendan.1@gmail.com; Géosciences Rennes UMR 6118, Campus de Beaulieu, Bât. 15, 263 av. du Général Leclerc, CS 74205, 35042 Rennes Cedex, France. 


\section{ABSTRACT}

This study proposed a new reconstruction of the tectono-sedimentary evolution of the Lake Albert Rift based on a biostratigraphical, sedimentological and structural re-evaluation of the outcropping data and on an exceptional subsurface dataset.

The infilling of the rift consists of lacustrine deposits wherein two major unconformities dated at 6.2 Ma and 2.7 Ma were characterized, coeval with major subsidence and climatic changes.

Combined with the fault analysis, the evolution and distribution of the subsidence highlights a foursteps evolution of the rift after its initiation dated at 17.0 Ma.

The first phase $(17.0-6.2 \mathrm{Ma})$ consists of low and diffuse extension associated with low accommodation rates ranging from 150 to $200 \mathrm{~m} / \mathrm{Ma}$. Restricted in the southern part of the basin, the depocenter location is poorly controlled by faults, meaning that the basin extension was potentially larger at this time.

The second time interval $(6.2-2.7 \mathrm{Ma})$ shows an increase of accommodation rates with values reaching more than $800 \mathrm{~m} / \mathrm{Ma}$. These high rates combined with the location of the major depocenters down the bounding faults argue for a first true rifting phase.

Between 2.7 Ma and 0.4 Ma, the accommodation rates decreases to reach less than $400 \mathrm{~m} / \mathrm{Ma}$ and the individualization of major depocenters continue down the major fault in the southern, and northwestern parts of the basin.

Finally, between $0.4 \mathrm{Ma}$ and present-day, a late uplift led the formation of the Ugandan scarp.

Comparison of the Lake Albert Rift evolution with the data available in the rifts of both branches of the East African Rift System shows that most of the sedimentary basins experienced the same geometrical evolution from large basins with limited fault control during Late Miocene to narrow true rift in Late Pleistocene. 


\section{INTRODUCTION}

Extending from the Afar triple junction in the north (northern Ethiopia) to the Funhalouro Rift (Limpopo Plain, Mozambique, Fig. 1a) in the south, the East African Rift System (hereafter referred to the EARS) is an incipient divergent boundary between three major tectonic plates: the Arabian, Nubian (African) and Somalian plates (Calais et al., 2006; Saria et al., 2014; Stamps et al., 2014, 2008). The rifts and associated sedimentary basins of the EARS are located on two broad elevated "domes", the Ethiopian and East African domes (Ebinger, 1989). These wide regions of anomalously high topography are related to the thermal and dynamic activity of one or several mantle plumes connected to the so-called African asthenospheric superswell or superplume (Burke, 1996; Ebinger and Sleep, 1998; George et al., 1998; Nyblade and Robinson, 1994; Pik et al., 2006; Ritsema et al., 1998; Simmons et al., 2007), potentially at the origin of the extension.

Although the EARS is one of the most extensively studied rifts in the world, several questions remain about (1) the age of the initiation of the rifts (e.g. Macgregor, 2015), (2) the age of the doming (pre- to post-rift; e.g. Pik et al., 2003), (3) the existence and the age of the rift shoulders (syn- or postrift; e.g. Bauer et al., 2016, 2012, 2010a; Spiegel et al., 2007; van der Beek et al., 1998) and (4) the different stages of evolution of the rifts and their relationships with the deformation. In the present study, we mainly focus on this last point though stratigraphical and structural analysis of one of the EARS basins, the Lake Albert Basin (Uganda) located at the northern termination of the western branch.

Three main types of sub-basins can be defined along the EARS: (1) rifts valleys superimposed or filled by volcanic rocks and few sediments with uplifted margins (eastern branch of the EARS - e.g. Gregory rift), (2) rift basins with few or no volcanic rocks and little uplift of the rift shoulders (e.g. Tanganyika and Malawi rifts) and (3) non-volcanic rift basins with an uplifted margin on one or both sides (e.g. Turkana, Albert and Rukwa rifts). The age of the volcanic rift initiation is documented on the basis of volcanic infilling dating (e.g. Ebinger, 1989a; Ebinger and Sleep, 1998; George et al., 1998; Kampunzu et al., 1998; Nyblade and Brazier, 2002; Pouclet et al., 2016; Zanettin et al., 1983). Conversely, the age of initiation and evolution of the non-volcanic and non-uplifted rifts are poorly 
known due to the absence of deep drillings reaching the substratum and the limited attention paid to the biostratigraphy of the sedimentary basins (e.g. Pickford et al., 1993; Van Damme and Pickford, 2003).

The aim of this study is to discuss the geological evolution of the Lake Albert Basin on the basis of new data (wells and 2D seismic dataset) and analysis of the outcropping sediments (biostratigraphy and sedimentology). Our objective is to propose (1) an age model for the sedimentary infilling and its sequence stratigraphic framework and (2) a new tectono-stratigraphic calendar for the Lake Albert Basin evolution.

\section{REGIONAL SETTINGS}

\subsection{THE EAST AFRICAN DOME RIFT SEGMENTS}

The EARS is divided into two branches, an eastern and western branch, surrounding an Archean craton and lying on Proterozoic mobile belts and following their preexisting crustal-scale fabric trends (e.g. Chorowicz and Sorlien, 1992; Corti et al., 2007; Morley, 2010). The eastern branch (or Kenyan rifts) extends from Lake Turkana in the north to a diffuse zone of extension referred to the Tanzanian Divergence in the south (Fig. 1a). This eastern branch is characterized by moderate seismic activity and significant magmatism. In contrast, the western branch, extending from the Azwa Precambrian lineament in the north (Fig. 1a-b) to Lake Malawi in the south, corresponds to a succession of seismically active asymmetric rifts segmented by transverse fault zones (TFZ; e.g. Bosworth, 1985; Chorowicz and Sorlien, 1992; Ebinger, 1989b; Morley, 2010, 1999; Rosendahl, 1987; Fig. 1b) and displays an alternating sense of asymmetry (Ebinger, 1989a). One of the characteristics of this western branch is the rare volcanic activity restricted to several provinces such as Toro-Ankole $(\approx 0.6 \mathrm{Ma})$, Virunga (first episode at $12.6 \mathrm{Ma})$, South Kivu $(\approx 21 \mathrm{Ma})$ and Rungwe $(\approx 8.6 \mathrm{Ma})$ (see review in Kampunzu et al., 1998 and Pouclet et al., 2016). South of the East African dome, the EARS expose a diffuse pattern of extension connected to the Davie Ridge in the south-east and propagating toward Namibia in the south-west where the Okavango Delta (Botswana) shows an incipient rifting stage (Fig. 1a). 
Along the eastern branch, magmatism began in the Late Oligocene - Early Miocene (Baker et al., 1971; Bishop et al., 1969; McDougall and Brown, 2009; Morley et al., 1999c) and ages tend to document an overall southward migration of the rifting though time until the Tanzanian Divergence (e.g. Baker, 1987; Baker et al., 1971; Ebinger, 1989a; Foster et al., 1997; George et al., 1998; Kampunzu et al., 1998, 1991). The timing of the western branch is uncertain because of the rare volcanic activity. On the basis of the oldest volcanic episodes occurring in the Virunga between 12.6 (Bellon and Pouclet, 1980) and 11 Ma (Kampunzu et al., 1998 and literature therein), the western branch is usually interpreted as being younger than the eastern branch. Nevertheless, recent studies based on new sediment analysis and dating (biostratigraphy, magnetostratigraphy) indicate that the rifting initiation probably began as soon as the late Oligocene in the Rukwa rift (Roberts et al., 2012, 2010).

For a long time, the direction of the present-day extension related to the EARS opening was debated as being either an oblique opening model consisting of a SE drifting of the Somalian plate (e.g. Chorowicz, 2005, 1990; Chorowicz and Mukonki, 1980; Daly et al., 1989; Kazmin, 1980; Scott and Rosendahl, 1989; Tiercelin et al., 1988; Wheeler and Karson, 1994) or an orthogonal opening model based on the actual overall E-W extension with a direction of extension that slightly varies along the two branches (e.g. Delvaux, 2001; Delvaux and Barth, 2010; Ebinger, 1989a; Lezzar et al., 2002; Morley, 2010, 1999; Morley et al., 1999b). Recently, both earthquake slip vector data and GPS geodesy studies support the second hypothesis of a general E-W extension (e.g. Calais et al., 2006; Delvaux and Barth, 2010; Saria et al., 2014, 2013, Stamps et al., 2014, 2008).

\subsection{THE ALBERTINE RIFT SYSTEM}

The Lake Albert Basin belongs to the Albertine Rift System which includes Lake Albert, Lake Edward and Lake George (Pickford et al., 1993). Bounded by the Azwa lineament to the north and by the Virunga volcanic province to the south (Figs. 1a \& 2), this system is characterized by an outstanding 5000 meter high relief located between Lake Albert and Lake Edward, the Rwenzori Mountains (Fig. 2). 
The Lake Albert Basin was traditionally considered as an asymmetric half-graben dipping to the north-west where the major bounding Bunia fault system (Fig. 2) probably led to the uplift of the 2100 m high Blue Mountains (Ebinger, 1989a and gravity modelling of Ebinger et al., 1991; Karner et al., 2000; Upcott et al., 1996). The eastern boundary consists of westward-dipping antithetic ToroBunyoro and Tonya fault systems (Fig. 2) which controlled the uplift of the 1200m high topographic escarpment observed at the eastern border of the lake (difference in elevation with the lake level of $\approx$ 400m). By matching the observed and modeled topography with free-air gravity, Karner et al. (2000) assumed a crustal extension ranging from 6 to $16 \mathrm{~km}$ for a sediment thickness up to $5 \mathrm{~km}$ deposited during 5 Ma. Recently, on the basis of new seismic data and gravity re-processing, Karp et al. (2012) shows that the Lake Albert Basin is rather a "full-graben" that "has subsided symmetrically and continuously in the Late Cenozoic along two extensive boundary fault systems on either side of the basin".

Focal mechanism (Delvaux and Barth, 2010) and GPS geodesic studies (Calais et al. 2006; Stamps et al. 2008) indicate that the Lake Albert Basin is currently opening at $2 \mathrm{~mm} / \mathrm{a}$ in a predominantly WNW-ESE extensional stress regime. However, localized earthquakes showing strike-slip solutions (e.g. Koehn et al., 2010; Ring, 2008), rare positive flower structures (splay geometry of faults) and anticline structures (Abeinomugisha and Kasande, 2012) suggest that the Lake Albert Basin might have experienced potential strike-slip movement during its evolution. These discussions about an oblique component could be explained by the basement structure heritage. South of the Nile, the Lake Albert Basin is located at the interface of the Archean Congo Craton and the Paleo- to MesoProterozoic Kibaran mobile belt of which the basin follows its roughly NE-SW trend.

The age of the rifting initiation in the Lake Albert Basin is debated because the first Early Miocene sediments preserved in the basin have not been considered as syn-rift deposits but rather as "pre-rifting fluvial sediments" (Ebinger, 1989a; Hopwood and Lepersonne, 1953). Based on the biostratigraphy available at this time, the first syn-rift lacustrine sediments were considered to be Late Miocene in age (8 Ma; Ebinger, 1989a; Pickford et al., 1993), following a first volcanic episode of the Virunga Province dated from 12.6 to 9.0 Ma (Kampunzu et al., 1998; Pouclet et al., 2016 and literature 
therein). This first major rifting phase might have been responsible for the formation of a paleo-lake (Lake Obweruka) covering the entire Albertine Rift area until the Rwenzori uplifted around $2.5 \mathrm{Ma}$ (Pickford et al., 1993; Taylor and Howard, 1999; Van Damme and Pickford, 2003). Recent petroleum exploration and biostratigraphical investigations argue for an older rifting initiation, uppermost Early Miocene in age ( $\approx 17.0 \mathrm{Ma}$; Abeinomugisha and Kasande, 2012).

The origin of the Rwenzori Mountains is still debatable. Both thermochronological (Bauer et al., 2016, 2015, 2012, 2010a; MacPhee, 2006) and biostratigraphical data (e.g. Pickford et al., 1993) indicated a last uplift during the Upper Pliocene to Pleistocene, mainly around 2.5 Ma. A first stage of exhumation probably compensated by erosion occurred during Jurassic times (Bauer et al., 2012). Seismological data, (Homuth et al., 2016; Wölbern et al., 2010) shows the absence of a crustal root and thinned crust below the Rwenzori Mountains. On the basis of microtectonic measurements and focal mechanism analysis, the tectonic setting of the Rwenzori Mountains is assumed to be dominated by strike-slip movements (e.g. Koehn et al., 2010; McConnell, 1959; Ring, 2008; Sachau et al., 2016). Two main mechanisms are proposed to explain the extreme uplift of the Rwenzori Mountains: (1) isostatic response related to the removal of crustal material in the hanging wall of a normal fault (Koehn et al., 2016, 2010); the horst uplift is thus the consequence of the "cantilever effect" (Kusznir and Ziegler, 1992), and (2) the delamination of the lower crust and mantle lithosphere due to preexisting weak-zones (Wallner and Schmeling, 2016, 2010).

By performing a sedimentary study of the Kisegi-Nyabusosi area outcrops, Roller et al. (2010) defined a four-staged evolution of the Lake Albert Basin: (1) from 14.5 to $10 \mathrm{Ma}$, the first stage corresponds to a sag basin with little accommodation space creation infilled by fluvial sediments. (2) From 10.0 to $4.5 \mathrm{Ma}$, the second phase is characterized by the creation of limited accommodation space and records successive rises in the lake level, as indicated by a transition from a distal fluvial plain to a lacustrine environment. The increase in the accommodation/sediment supply ratio is believed to record an initial rifting activity. (3) Between 4.5 and $2 \mathrm{Ma}$, the third stage corresponds to a classic rift controlled by sediment-supply rather than by accommodation. The lacustrine deposits record lake-level highstands. (4) Finally, from 2 to $1.5 \mathrm{Ma}$, an overall increase in the subsidence 
associated with a significant sediment supply is responsible for the acceleration of the uplift of the flanks. This infilling corresponds to stacked transgressional cycles from a fluvial to lacustrine environment.

\section{MATERIAL AND METHODS}

\subsection{DATA AVAILABLE}

The study of the Lake Albert Basin presented herein is based on the analysis of field and subsurface data. The field data consist of numerous short sections (from 5 to 170m, Fig. 3) on which both sedimentological and biostratigraphical analyses were performed, most of them having previously been studied by Pickford and co-authors (e.g. 1993). The outcropping areas are restricted in (1) the Kisegi-Nyabusosi area, at the northern tip of the Rwenzori Mountain (the so-called Semliki area), (2) in the Kaiso-Tonya flat, on the central eastern shore of Lake Albert and (3) in the northern part of the lake (Fig. 3). The subsurface dataset consists of approximately 300 2D seismic lines and 20 interpreted wells. Here, we present the interpretation of 11 regional seismic lines and five wells selected in order to represent the characteristic geometrical configurations of the Lake Albert Basin (sections 1 to 11 and wells 1 to 5; Fig. 3). In addition to five exploration wells, two fictive wells resulting from seismic interpretation (well A and B; Fig. 3) are presented in order to illustrate the most subsiding part of the basin. Unfortunately, these data are limited to the Ugandan side of Lake Albert.

\subsection{BASIN-SCALE CORRELATIONS}

Stratigraphic cycles - transgressive and regressive cycles - were interpreted from the evolution of the sedimentary environments (alluvial to distal lacustrine). These environments were defined on the basis of (1) sedimentary facies analysis of the outcrops, (2) the palynomorph content (pollens and spores in wells and outcrops) and (3) the well-log signatures of the sedimentary facies.

By definition, the stratigraphic cycles are bounded by Maximum Regressive Surfaces (MRS Catuneanu et al., 2009) which correspond to the most proximal environment. In between, Maximum Flooding Surfaces (MFS; Posamentier and Allen, 1999) are defined. These surfaces are marker of the most distal environment and represent turnaround surfaces between transgressive and regressive 
trends. Unconformities (Un; Embry, 2009) can occur during the regression and record either an aerial erosional surface or a downward shift of the sedimentary facies in a subaqueous environment.

Depending on the distance separating the wells, basin-scale correlations were performed in two different ways. In the case of wells separated by several kilometers (e.g. Kaiso-Tonya flat), correlations are made by applying stacking pattern techniques (Homewood et al., 1992; Van Wagoner et al., 1990, 1988) and then validated by the characteristics of the algae, pollen and spore trends (e.g. maximum amount of Botryococcus, Pediastrum, Podocarpus or Poaceae). Three cycle orders were defined, possibly $3^{\text {rd }}, 4^{\text {th }}$ and $5^{\text {th }}$; the latter was only used for the stacking pattern correlations. When wells are separated by several tens of kilometers, correlations were made in favor of the major stratigraphic cycles and were strongly constrained by the palynomorph records.

\subsection{SEISMIC INTERPRETATION}

The 2D seismic reflection dataset mainly displays a parallel configuration of reflection, with very few localized divergent or sigmoidal (prograding clinoforms) reflectors. Consequently, the classical seismic stratigraphy analysis using truncations (Vail et al., 1977) and offlap migration ("shoreline trajectory" sensu Helland-Hansen and Martinsen, 1996) cannot be applied successfully in the Lake Albert Basin. The only variations concerned the seismic facies packages and the continuity, amplitude and frequency of the reflectors. This implies that the stratigraphic surfaces (MFS, MRS, Un) were first defined from the wells and then propagated to the seismic lines. The structural analysis (mainly fault distribution and geometries) was performed using several reasonable vertical exaggerations (1:1 to $1: 2)$

Both sediment thickness and sedimentation rate maps were compiled for three time intervals. Sedimentation rate maps (under-compacted) are used as a proxy of the spatial distribution of the accommodation rate. In addition, eleven regional sections based on the $2 \mathrm{D}$ seismic interpretation illustrate the relationships between the structure and sedimentation. Regional $2 \mathrm{D}$ sections and thickness maps (isopach maps) were converted into depth using a time (ms) to depth (m) conversion law constrained by the wells and provided by the petroleum company Total. 


\subsection{AGE MODEL}

Pickford et al. (1993) divided the outcropping Neogene and Quaternary sedimentary succession of the Lake Albert Basin into eight lithostratigraphic formations in the Kisegi-Nyabusosi area and into four major formations in the Kaiso-Tonya area (see Fig. 3 for the location and $\$ 1.4 .2$ for a detailed description). This subdivision of the sedimentary infilling is based on lithologies and biostratigraphic content such as mammals (e.g. Pickford et al., 1993 and literature therein), mollusks (Van Damme and Pickford, 1994) and, more recently, pollens, pores and algae (Lukaye, 2009; Shaw et al., 2009). Mammals are the only fossils that can be used for calibration on the international chronostratigraphic chart (Gradstein et al., 2012). Mollusk associations are limited to the Albertine rift area and Neogene pollens and spores mainly record environmental changes driven by the climate. In this study, vertebrate biozonations are calibrated in ages in (1) Kenya, where radiometric dating of tuffs and lavas constrain the age of the vertebrate taxon ranges or, when species were not described in Kenya, (2) in favor of the international European vertebrate biozones chart. The time range of each vertebrate taxon is reported on the stratigraphic sections (and thus, on the associated lithostratigraphic formations) and, according to their degree of evolution, classified into five main categories: primitive, early, mature, late and end of phylum. For each formation, the common range of the different characteristic vertebrate species defines a time-interval for the considered lithostratigraphic units (Yalden, 2011).

The first limit of this approach is the use of mammals as dating elements because (1) their preservation is highly controlled by the type of sedimentary environment, (2) for some time intervals, few (or no) species were sampled and (3) the time range of some species is poorly constrained. The second limit is that these mammals were only found on outcrops. Thus their ages need to be propagated in the subsurface data using sequence stratigraphy and paleo-environmental data (pollens and spores record) correlations.

For these reasons, we proposed to test the outcrop age model extended to the wells by doing a comparison with the regional paleo-climatic charts. The basin-scale climatic chart is based on the following assumptions: humid conditions are related to periods of maximum lake growth emphasized by Botryococcus algae and more arid conditions correspond to a minimum lake extension (large 
alluvial plains and littoral environments) highlighted by an increase in aerial flora, i.e. Poaceae. Transitions from humid to arid conditions correspond to a sharp decrease in water depth, i.e. unconformities. This basin-scale climatic signal is then compared to the dated regional climatic chart, here mainly the one of Bonnefille, (2010) based on the "tree cover" of East-Africa estimated from the percentages of tree and shrub pollens.

\subsection{ACCOMMODATION SPACE MEASUREMENT}

In order to quantify the vertical displacement within the Lake Albert Basin (subsidence and uplift), the accommodation space was measured using the backstripping method (e.g. Watts and Steckler, 1979). Accommodation is defined as the space created in the sea, or in a lake, in response to the vertical movement of the base of the basin (relative to lithospheric/mantellic deformation) and the lake level, a consequence of the hydrological budget related to climatic variations. This is not a direct measurement of the subsidence because we were not able to remove the lake level variations related to the climatic variations. Nevertheless, a change in the vertical facies from a shallow lake to a coastal plain or alluvial plain environment, suggests moderate variations in the lake level and thus indicates that most of the accommodation space creation is controlled by tectonic vertical movements.

Accommodation measurements require: (1) previously defined (§ 3.2) time-lines (turnaround surfaces, MFS and MRS or unconformities, Un) and are referred in absolute ages ( $\S 3.3 .4)$, (2) porosity data deduced from well-log signatures and cuttings and (3) an estimation of the paleo-depths interpreted from facies analysis (outcrops analysis, well-log signatures and palynological content). The decompaction is based on the depth-porosity coefficient for the different lithologies, here mainly clay and sand. Different scenarios were tested by applying uncertainty ranges associated with the absolute ages, paleo-depths and lithologies.

Accommodation space variations were measured in five wells (wells 1 to 5; Fig. 3). In addition, two "fictive wells" interpreted from the $2 \mathrm{D}$ seismic lines aim to illustrate the accommodation variations in the most subsiding parts of the basin where no wells are available (wells A and B; Fig. 3). 


\section{RESULTS}

\subsection{DEPOSITIONAL MODEL AND SEQUENCE STRATIGRAPHY ANALYSIS}

\subsubsection{Depositional model}

Five major facies associations (referred as $\mathrm{Fa}$ ) were defined on the outcrops and well-logs in the infilling of the Lake Albert Basin (Fig. 4): distal "deep" lacustrine (Fa1), proximal "shallow" lacustrine (Fa2), deltaic lacustrine (Fa3), lacustrine shoreline and embayment to lacustrine coastal plain (Fa4) and alluvial plain environments (Fa5).

\subsubsection{Distal "deep" lacustrine (Fa1)}

It essentially corresponds to homolithic, massive or horizontally laminated dark grey clays. Some intervals can be either more silty or organic-rich with abundant Botryococcus algae. The biological content is poor, with rare in-situ freshwater bivalves (with connected shells) but no bioturbations.

The depositional setting is the one of a perennial lake (freshwater algae and bivalves) as indicated by the lack of mud-cracks or soils (even hydromorphic).

In the subsurface, the well-log signature of this environment consists of a high natural radioactivity (gamma-ray) and a symmetrical evolution of the density and porosity (Fig. 4). More radioactive intervals correspond to an organic-rich clayey interval.

\subsubsection{Proximal "shallow" lacustrine (Fa2)}

These environments consist of an alternation of clays (Fa1) and coarse- to fine-grained sands several to tens of centimeters thick. These sandy beds are most of the time poorly sorted, structure-less (massive) and do not show either normal or reverse grading. Some of them show crude planar horizontal laminations (upper flow regime) or provide evidence of fine-grained sand with bedload current ripple cross-beddings (no occurrence of climbing current ripple cross-beddings). Pediastrum are observed in the clayey intervals.

These lacustrine beds do not correspond to either classical lacustrine turbidites (no normal grading, no Bouma or Stow sequences; e.g. Wells et al., 1999) or to hyperpicnal flows (no reverse grading, no climbing current ripples; e.g. Olariu and Steel, 2009; Olariu et al., 2010). They look similar to sheet- 
flood deposits directly supplied from the aerial domain (structure-less, poorly graded and sorted) such as the classical examples of Turner (1973) or Mutti et al. (2000).

The well-log is characterized by high variations (thin peaks) of radioactivity (low and high gammaray) and porosity values (from clay to sand; Fig. 4). The overall gamma-ray trend generally exposes a slight funnel shape (slight coarsening upward trend).

\subsubsection{Lacustrine delta $(\mathrm{Fa3})$}

Lacustrine deltas are mainly made up of homolithic coarse-grained sand organized in coarsening upward units (from medium- to coarse-grained sand) of several meters with 2D-3D (sinuous crest) to 3D current megaripples, some of which are climbing (mixed bedload - suspended-load transport; Allen, 1981). On another scale, these megaripples are superimposed onto sand bars (wavelength > $10 \mathrm{~m}$ ) forming compound cross-beddings. Both the bars and megaripples migrate in the same direction. The clayey intervals contain a significant amount of Pediastrum algae.

The occurrence of climbing megaripples and compound cross-beddings (indicating sand bars) are characteristic of mouth bars along a river delta-front system (e.g. Coleman and Wright, 1975; Galloway, 2001; Olariu et al., 2012).

The high porosity and funnel shape (coarsening upward) of the low gamma-ray values are a characteristic response of a prograding mouth bar in the well-logs.

\subsubsection{Lacustrine shoreline and embayment (Fa4)}

These deposits correspond to green to grey clays interbedded by fine- to medium-grained sandy beds (from tens of centimeters to two meters thick). The clays are green to grey, massive and occasionally silty and frequently lignite-rich. The sandy facies mainly consist of well-sorted highly bioturbated and clean sandstones with current and avalanching ripples and megaripple cross-beddings and locally numerous gastropod debris (coquina) and various plant residues.

These facies suggest a deposition in a lacustrine shoreline to coastal plain environment with embayment and marshes (lignite). 
The clayey facies of this environment are characterized by high radioactivity (gamma-ray), high porosity and low density values; the last two curves evolve symmetrically and record woodland plant and lignite debris (Fig. 4).

\subsubsection{Lacustrine coastal plain (Fa5) and river channels (Fa6)}

Lacustrine coastal plain (Fa5) environment consists of massive dark-grey to green clays with plants debris, hydromorphic soils and a significant amount of aerial Poaceae (Gramineae) pollens.

River channel (Fa6) facies are sometimes interbedded in these coastal plain clays. These facies correspond to very-coarse- to medium- grained sands organized in fining-upward sequences (several meters thick) with 2D and 3D current megaripple cross-beddings. The base of these sandy units is sharp and erosional and sometimes topped by thin intervals of pebbly to conglomeratic sandstones (lag).

The fining-upward trend within the cross-bedded sands is characteristic of distributary fluvial channels in an alluvial plain (e.g. Allen, 1965; Miall, 2006).

The channel well-log signature consists of low radioactivity values showing bell shapes (finingupward trend) and a rapid shift of the gamma values at the base (Fig. 4).

\subsubsection{Paleo-bathymetry}

The absence of turbidite and hyperpicnal flows suggests a quite flat domain with no major slopes and thus a quite shallow lake, not very different from the present-day one (average depth of $25 \mathrm{~m}$; e.g. Howard and Karundu, 1992). This is supported by the rare occurrence of clinoforms on the seismic lines and the parallel and continuous configuration of the seismic reflector along which the facies evolves from distal lacustrine to coastal plain environments. The clinoforms are not higher than $100 \mathrm{~m}$.

\subsubsection{Sequence stratigraphy analysis: basin-scale correlations}

Five major cycles with a mean duration of 2 to 5 Ma ( $3^{\text {rd }}$ order;Figs. $\left.5 \& 6\right)$ were identified and correlated on both the outcrops and wells based on the facies variation defined above. Numerous cycles of shorter duration ( $4^{\text {th }}$ to $5^{\text {th }}$ orders) were identified offshore and correlated from well to well with respect to their stacking pattern (Fig. 5). 
Cycle $1\left(\mathrm{~S}_{\mathrm{Un}}-\mathrm{S} 1_{\mathrm{r}}\right)$ is a highly asymmetrical cycle; its transgressive trend is locally recorded as the transition from a $0-2 \mathrm{~m}$ thick poorly-sorted conglomerate overlying a weathered basement to lacustrine facies. The regressive half-cycle corresponds to the shift from mouth bars (Fa3) to coastal plain (lignitic clays, Fa5) and alluvial facies (distributary channel, Fa6; $\mathrm{S}_{\mathrm{r}} \mathrm{MRS}$ ).

Cycle $2\left(\mathrm{~S}_{\mathrm{r}}\right.$ to $\left.\mathrm{S} 2_{\mathrm{r}}\right)$ is one of the most lacustrine-dominated cycles (with cycle 3, C3) as indicated by the distal clays (Fa1) which are characterized by large amount of organic material and intervals that are very rich in Botryococcus algae, illustrating the maximum flooding $\left(\mathrm{S} 2_{\mathrm{m}}\right)$. The regressive trend is characterized by the transition from flood deposits (alternating clays and sandy sheet-floods, Fa2) to the mouth bar $(\mathrm{Fa} 3)$ where the MRS is positioned $\left(\mathrm{S}_{\mathrm{r}}\right)$.

Cycle $3\left(\mathrm{~S}_{\mathrm{r}}\right.$ to $\left.\mathrm{S} 3_{\mathrm{r}}\right)$ is the most lacustrine cycle. It is dominated by clays (with Botryococcus and organic material) and heterolithic clay-sand alternations (flood lobes). The regressive trend is characterized by a major unconformity $\left(\mathrm{S}_{\mathrm{Un}}\right)$ coeval with a sharp facies transition from distal lacustrine deposits (Fa1) to proximal mouth bars (Fa3) and alluvial deposits ( $\mathrm{Fa} 5$ and $\mathrm{Fa} 6 ; \mathrm{S}_{\mathrm{r}}$ MRS). This transition is concomitant with a change in algae species from Botryococcus to Pediastrum and an increase in Poaceae pollens.

Cycle $4\left(\mathrm{~S}_{\mathrm{r}}\right.$ to $\left.\mathrm{S} 4_{\mathrm{Un} 2}\right)$ shows all the facies from the distal lacustrine $(\mathrm{Fa} 1)$ to deltaic sheet-flood (Fa2 and $\mathrm{Fa} 3)$, coastal plain $(\mathrm{Fa} 5)$ and alluvial plain environments $(\mathrm{Fa} 6)$. The lack of a significant amount of Botryococcus indicates that the most lacustrine facies $\left(\mathrm{S} 4_{\mathrm{m}}\right)$ are not as distal and "deep" as cycles 2 and 3. The regressive half-cycle is characterized by two $4^{\text {th }}$ order unconformities $\left(\mathrm{S}_{\mathrm{Un} 1}\right.$ and $\left.\mathrm{S} 4_{\mathrm{Un} 2}\right)$, the most important being the youngest one $\left(\mathrm{S} 4_{\mathrm{Un} 2}\right)$. It records a sharp transition from distal lacustrine to lacustrine shoreline (Fa4) and alluvial plain environments (fining-upward sequences; Fa6).

Cycle 5 ( $\left(\mathrm{S}_{\text {un2 } 2}\right.$ to the present day) is dominated by aerial alluvial deposits with Poaceae and Podocarpus pollens, this latter species being characteristic of high elevations. The maximum flooding $\left(\mathrm{S}_{\mathrm{m}}\right)$ is located in shallow lacustrine clays with an instant increase in Botryococcus and Pediastrum algae. 


\subsection{AGE MODEL}

Several attempts to date sediments using fauna (mollusks, vertebrates) were made from the 1920's to the 1970's on isolated outcrops of the Kisegi-Nyabusosi and Kaiso-Tonya areas (e.g. Adam and Lepersonne, 1959; Bishop, 1971, 1965; Cooke and Coryndon, 1970; Gautier, 1965; Hooijer et al., 1963; Hopwood, 1926; Hopwood and Lepersonne, 1953; Lepersonne, 1949; MacInnes, 1942; Wayland, 1926). Nevertheless, the first dating based on a clear lithostratigraphy nomenclature was proposed by the Uganda Palaeontology Expedition at the turnaround of 1980's/1990's (e.g. Pickford et al., 1993).

Vertebrates are only preserved in the Kisegi-Nyabusosi area (Fig. 2), south of Lake Albert, where six formations were dated (Kisegi, Kakara, Oluka, Nyaburogo, Nyakabingo, Nyabusosi Formation; Fig. 6) and in the Kaiso-Tonya area (Fig. 3), on the eastern shore of Lake Albert where four formations were defined (Nkondo, Warwire, Kyeoro and Kaiso-Village Formations) (Pickford et al., 1993).

Located on the Congolese side of the rift (Sinda and Karugamania sites; Pickford et al., 1993; Yasui et al., 1992), the oldest sediments are Early Miocene in age as illustrated by the presence of Deinotherieum hobieyi and Brachyodus aequatorialis. On the Ugandan side, the first sediments are dated at the second-half of the Middle Miocene (Kasande Member, upper part of the Kisegi Formation, $12.5 \mathrm{Ma}$ ) by vertebrate fossils including Pleidon moharensis as well as a small Rhinocerotidae paradiceros mukirii. The Late Miocene is characterized by the Kakara (11.5 - 9.0 Ma) and Oluka (6.5 - 5.0 Ma) formations whose the most characteristic fossils are Tetralophodon anthracothere, Stegotetrabelodon, Primelephas gomphotheroides, Nyanzachoerus syrticus. The Early Pliocene corresponds to the Nyaburogo Formation (4.2 - 5.0 Ma) in the Kisegi-Nyabusosi area and to the Nkondo $(5.1-4.6 \mathrm{Ma})$ and Warwire $(\approx 4 \mathrm{Ma})$ Formations in the Kaiso-Tonya area. This time interval is characterized by numerous vertebrates including Mammuthus subplanifrons, Torolutra ougensis or different species of Nyanzachoerus. The Nyakabingo Formation of the Kisegi-Nyabusosi area and the Kyeoro (4.6-2 Ma) and Kaiso-Village ( $\approx 2.2 \mathrm{Ma})$ Formations of the Kaiso Tonya area correspond to the Upper Pliocene with vertebrates including species of Loxodonta, Elephas, 
Kolpochoerus or Giraffa. The transition between the Pliocene and Pleistocene is associated with the Nyabusosi Formation ( $\approx 1.5 \mathrm{Ma})$, in which examples of Elephas recki atavus or Kolpochoerus majus were found. Notice that several time intervals were not covered by the life range of the vertebrate fossils found in the outcropping areas (e.g. 0.6 Ma between the Kisegi and Kakara formations or 2.5 Ma between the Kakara and Oluka formations; Fig. 6).

The propagation of the proposed age model in the subsurface requires a climatic chart based on the correlation of the outcrops of the Kisegi-Nyabusosi and Kaiso-Tonya areas dated by vertebrates and subsurface data where a complete palynomorph record exists.

From the outcrops to the wells, five main stratigraphic $3^{\text {rd }}$ order cycles were correlated. In addition, the $4^{\text {th }}$ and $5^{\text {th }}$ order cycles were correlated offshore with respect to their stacking patterns (Figs. $5 \&$ 6). The first $3^{\text {rd }}$ order cycle (C1, Lower Kisegi Formation - Early Miocene) corresponds to a relatively humid period as illustrated by a significant amount of Pediastrum. The second cycle (C2, Upper Kisegi Formation to Lower Kara Formation - Uppermost Early Miocene to the first half of the Upper Miocene) shows a major flooding highlighted by a peak of Botryococcus algae both on the outcrops and wells ( $\left.\mathrm{S} 2_{\mathrm{m}} \mathrm{MFS}\right)$. The third cycle (Upper Kakara Formation to Oluka Formation - Late Miocene) is the most humid, with a significant amount of Pediastrum and Botryococcus and rare Poaceae. A peak of Botryococcus emphasized a second major flooding $\left(\mathrm{S}_{\mathrm{m}}\right)$ while the instant appearance of Poaceae is associated with the $\mathrm{S} 3_{\mathrm{Un}}$ unconformity. The $4^{\text {th }}$ cycle $(\mathrm{C} 4$, Nyaburogo and Nyakabingo Formations - Pliocene) records an overall aridification highlighted by an increase in Poaceae and the transition from distal to coastal lacustrine environments. Unconformities $\left(\mathrm{S} 4_{\mathrm{Un} 1}\right.$ and $\mathrm{S} 4_{\mathrm{Un} 2}$ ) are associated with the disappearance of Pediastrum in favor of Poacea. The last cycle (C5, Nyabusosi Formation - Pleistocene) marks the return of a more humid climate, as suggested by the increase in Botryococcus and Pediastrum.

This climatic signal of the Lake Albert Basin based on algae, pollen and spore trends is in good agreement with the regional climatic chart published by Bonnefille (2010) (Fig. 6). The maximum lake extensions interpreted from the significant amounts of Botryococcus $\left(\mathrm{S} 2{ }_{\mathrm{m}}\right.$, Cycle C2 MFS; $\mathrm{S} 3_{\mathrm{m}}, \mathrm{Cycle}$ 
C3 MFS; S5 $5_{m}$, Cycle C5 MFS) are associated with large-scale tree coverage in Africa (humid period of Bonnefille, 2010) while the increase in Poaceae observed close to the $\mathrm{S} 3_{\mathrm{Un}}, \mathrm{S} 4_{\mathrm{Un} 1}$ and $\mathrm{S} 4_{\mathrm{Un} 2}$ unconformities are coeval with arid periods (savannah or glaciation, Bonnefille, 2010; Fig. 6). This comparison is also a way to clarify the dating of the turnaround surfaces using the time range of the humid and arid periods as the interval of occurrence of MFS and MRS.

\subsection{ACCOMMODATION EVOLUTION}

Both the cumulative accommodation space and accommodation rates were measured for seven time lines $\left(\mathrm{S} 1_{\mathrm{Un}}, \mathrm{S} 2_{\mathrm{m}}, \mathrm{S} 3_{\mathrm{m}}, \mathrm{S} 3_{\mathrm{Un}}, \mathrm{S} 4_{\mathrm{m}}, \mathrm{S} 4_{\mathrm{Un} 1}\right.$ and $\left.\mathrm{S} 4_{\mathrm{Un} 2}\right)$ using an average compaction hypothesis (Fig. 7). The variation in both the trends and rates is broadly the same regardless of which well is considered, with maximum rates around the Miocene-Pliocene boundary. The accommodation curves show three major periods bounded by two major unconformities ( $\mathrm{S} 3_{\mathrm{Un}}, 6.2 \mathrm{Ma}$ and $\mathrm{S} 4_{\mathrm{Un} 2}, 2.7 \mathrm{Ma}$; Fig. 7).

Time interval $1\left(\mathrm{~S}_{\mathrm{Un}}-\mathrm{S} 3_{\mathrm{Un}}\right)$ : Early $(17.0 \pm 0.8 \mathrm{Ma})$ to Middle $(6.2 \pm 0.2 \mathrm{Ma})$ Miocene: with mean values of 150 to $200 \mathrm{~m} / \mathrm{Ma}$, the rate of accommodation space creation is the slowest of the basin history. The sediment accumulation is located in the southern half of the basin and accommodation increases southward, with the cumulated accommodation ranging from $500 \mathrm{~m}$ (wells 3 to 5 ; central part) to more than $2500 \mathrm{~m}$ (wells 1,2 , and B; southern to central part). This time interval is subdivided in two sub-periods: (1) the $\mathrm{S} 1_{\mathrm{Un}}-\mathrm{S} 2_{\mathrm{m}}(17.0 \pm 0.8 \mathrm{Ma}$ to $12.4 \pm 0.4 \mathrm{Ma})$ interval shows moderate accommodation rates ( $<300 \mathrm{~m} / \mathrm{Ma}$, except in well B) while (2) the $\mathrm{S} 2_{\mathrm{m}}-\mathrm{S} 3_{\mathrm{Un}}(12.4 \pm 0.4$ Ma to $6.2 \pm$ $0.2 \mathrm{Ma}$ ) interval highlights a significant decrease from $\approx 250 \mathrm{~m} / \mathrm{Ma}$ to $125 \mathrm{~m} / \mathrm{Ma}$ in the most subsiding parts of the basin (wells A and B).

Time interval $2\left(\mathrm{~S}_{\mathrm{Un}}-\mathrm{S} 4_{\mathrm{Un} 2}\right)$ : Middle Miocene $(6.2 \pm 0.2 \mathrm{Ma})$ to Uppermost Pliocene $(2.7 \pm 0.2$ $\mathrm{Ma)}$ : the $\mathrm{S}_{\mathrm{Un}}$ unconformity marks a sharp increase in the accommodation rates in the whole basin with mean values higher than $500 \mathrm{~m} / \mathrm{Ma}$. In the most subsiding areas (southern and central part of the Lake Albert Basin), the accommodation frequently exceeds 600-800 m/Ma. Exceptions are observed on the footwalls of the Butiaba and Semliki faults (Kaiso-Tonya and Semliki compartments) where the sediment thickness is thinner (wells 3 and 4 , see below). The $\mathrm{S} 4_{\mathrm{Un} 2}$ unconformity is coeval with a sharp decrease in the accommodation rates from $600-800 \mathrm{~m} / \mathrm{Ma}$ to $100 \mathrm{~m} / \mathrm{Ma}$. 
Time interval 3 ( $\left(\mathrm{S}_{\mathrm{Un} 2}\right.$ - Lake-floor): Uppermost Pliocene $(2.7 \pm 0.2 \mathrm{Ma})$ to the Present Day: The mean accommodation rate is significantly decreasing from $450 \mathrm{~m} / \mathrm{Ma}\left(\mathrm{S} 4_{\mathrm{Un} 2} ; 2.7 \pm 0.2 \mathrm{Ma}\right)$ to 250 $\mathrm{m} / \mathrm{Ma}$ (present day) in the most subsiding part of the basin (wells 1, 2, A and B). The erosion of the uplifted Kaiso-Tonya and northern Butiaba areas led to the infilling of their accommodation space during this time interval.

\subsection{ACCOMMODATION DISTRIBUTION AND INFILLING GEOMETRY: ISOPACH MAPS AND REGIONAL SECTIONS}

\subsubsection{Main geometries and fault patterns*}

The main characteristic of the Lake Albert Basin is the symmetrical graben geometry of the central segment. Both the thickness map and regional sections show that four major faults accommodate the sedimentation between the $\mathrm{N} 40^{\circ}$ to $\mathrm{N} 60^{\circ}$ striking, $80-70^{\circ}$ dipping bounding fault systems (Bunia fault on the Congolese side and Toro-Bunyoro and Tonya fault systems on the Ugandan side, Figs. $2 \& 8$ ). Parallel to the $\mathrm{N} 70^{\circ}$ dipping Toro-Bunyoro bounding fault system, the $\mathrm{N} 60^{\circ}$ striking, $60^{\circ}$ dipping Butiaba fault delimitates the Kaiso-Tonya compartment (Fig. 9; section 4). In the south-eastern part of the basin, the $\mathrm{N} 80^{\circ}$ Semliki fault dips toward the NW at an angle of $50^{\circ}$ and individualizes the Semliki compartment (Fig. 9a; section 2). These compartments predominantly exposed parallel reflectors with only slight unclear thinning of the infilling toward the major faults (Fig. 9). The sedimentation consists of predominantly tabular stacking of the sediments, showing thickness variations on each side of the major faults (e.g. Butiaba and Semliki fault; Fig. 9; sections 2, 4 and 5). Thickness variation are only observed along the axis of the rift (thinning toward the north, Figs. $8 \& 9$; sections a and b). In the central part of the basin, the Kaiso-Tonya flat constitutes a structurally complex relay-ramp zone where the $\mathrm{N} 40^{\circ}$ Tonya fault system and $\mathrm{N} 60^{\circ}$ Toro-Bunyoro fault system are overlapping (Fig. 8). Connected to the Kaiso-Tonya flat, the $\mathrm{N} 140^{\circ}-\mathrm{N} 160^{\circ}$ Ngassa transverse fault subdivides the basin into two sets, the southern one being thicker than the northern one. A last major $\mathrm{N}^{\circ} 40$ striking, $40^{\circ}$ dipping fault, the Rwenzori fault, is observed at the northern tip of the Rwenzori Mountains, south of Lake Albert (Figs. 8 \& 9, section 2). 
Displacements related to the major $\mathrm{N} 40-60^{\circ}$ fault family gradually die out in diffuse zones of deformation, the Butiaba and Semliki transfer fault zones (TFZ; Figs. 8 \& 9). Essentially observed in the Butiaba TFZ, a secondary $\mathrm{N} 20^{\circ}$ fault group shows a relative short length and small throw and is connected to the $\mathrm{N} 60^{\circ}$ trending fault. These faults are responsible for the horst and graben configuration of this TFZ. This northern Butiaba TFZ, like the southern Semliki TFZ, exposed a complex highly faulted pattern (Fig. 9a-b, sections 6, 7, c, d) where several folded (pop-up like) structures and "ramp-and-relay shapes" of the fault planes are locally observed.

\subsubsection{Deformation evolution}

The seismic data exposed numerous onlapping terminations of the basal sediments on the basement unconformity $\left(\mathrm{S} 1_{\mathrm{Un}}\right)$ but the infilling does not present any obvious growth strata (structural wedges). "Pre-rift" structures are locally observed below the $S 1_{\text {Un. }}$ Mainly located to the south of Lake Albert, these "valley-like" structures are approximately 500m deep and $4 \mathrm{~km}$ wide and show an onlapping reflector but no growth strata (Fig. 9, section 3). Some of these structures are asymmetric and controlled by a fault on one of their sides.

From the early to upper Miocene (time interval 1; $\mathrm{S} 1_{\mathrm{Un}}-\mathrm{S} 3_{\mathrm{Un}}$ ), sedimentation occurs all over the basin with a maximum accommodation space creation in the southern part, between the $\mathrm{N} 80^{\circ}$ striking, $50^{\circ}$ dipping Semliki transverse fault and the N140-N160 ${ }^{\circ}$ striking, $70^{\circ}-60^{\circ}$ dipping Ngassa fault. During this period (mostly between $S 1_{\mathrm{Un}}$ and $S 2_{\mathrm{m}}$ ) of moderate sedimentation rates (50 to $250 \mathrm{~m} / \mathrm{Ma}$ ), sharp thickness variations along the NE-SW (Butiaba fault) to ENE-WSW faults (Semliki TFZ) form tabular and roughly isopach compartments (Kaiso-Tonya and Semliki compartments, Fig. 8). The infilling is also thicker south of the Ngassa faults (Fig. 8; section a). During this time interval $\left(\mathrm{S}_{\mathrm{Un}}-\right.$ $\left.\mathrm{S} 3_{\mathrm{Un}}\right)$, the finite displacement on the basin base $\left(\mathrm{S} 1_{\mathrm{Un}}\right)$ ranges from $1000 \mathrm{~m}$ to $1600 \mathrm{~m}$ down the Butiaba fault (Fig. 9a, section 5), 1200m down the Rwenzori fault (Fig. 9a, section 1), 800m down the Semliki fault (Fig. 9a, section 2) and 1500m south of the Ngassa fault (Fig. 9b, section a).

The second time interval (time interval 2; $\mathrm{S} 3_{\mathrm{Un}}-\mathrm{S} 4_{\mathrm{Un} 2}$ ) shows a sharp increase in the sedimentation rates in the whole basin (up to more than $600 \mathrm{~m} / \mathrm{Ma}$, Fig. 8). The accommodation space creation migrates northward, beyond the Ngassa fault. Several depocenters (thickness > 1600m; Fig. 8) are 
individualized (1) to the north-west of the basin, down the SW-NE Butiaba fault, (2) in the central part, down the $\mathrm{N} 140^{\circ}$ Ngassa fault and (3) to the west of the $\mathrm{N} 40^{\circ}$ Rwenzori fault in the southern corner of the basin (Fig. 8).

During this period $\left(\mathrm{S} 3_{\mathrm{Un}}-\mathrm{S} 4_{\mathrm{Un} 2}\right)$, the finite displacement on surface $\mathrm{S} 3_{\mathrm{Un}}$ ranges from $500 \mathrm{~m}$ to $800 \mathrm{~m}$ west of the Rwenzori and Semliki faults, 800 to $1000 \mathrm{~m}$ down the Butiaba fault and around $500 \mathrm{~m}$ south of the Ngassa fault. The infilling consists of a thick isopach interval (up to 2000m, Fig. 9) characterized by a configuration of parallel reflectors. $S 4_{\mathrm{Un} 1}-\mathrm{S} 4_{\mathrm{Un} 2}$ interval is locally marked by discrete differential accommodation and localized low stand wedges (Fig. 9; sections 5, b and c).

The Pleistocene (time interval 3; $\mathrm{S} 4_{\mathrm{Un} 2}$ - Lake-floor) shows an overall trend of sediment thickening toward the central part of the basin (up to $1500 \mathrm{~m}$; Fig. 8) with the individualization of a major depocenter located down the Butiaba fault. The thickness distribution highlights erosion on the KaisoTonya flat and in the northern termination of the basin. Another area of maximum accommodation space creation is located west of the Rwenzori fault (1500m, Fig. 8). Compared to the second time interval, the sedimentation rates decrease uniformly in the whole basin (from 500-600 m/Ma to less than 300 m/Ma; Fig. 8).

During this period, the fault throw gradually dies out. The finite displacement decreases in the whole basin and rarely exceeds $300 \mathrm{~m}$. The seismic quality associated with this interval is poor. However, the differential subsidence is highlighted by some unclear low stand wedges and the Pleistocene series are onlapping the $S 4_{U n 2}$ unconformity in the northern uplifted part of the basin (Butiaba area, Fig. 9, sections a and b).

\subsection{ALBERT RIFT EVOLUTION}

The Lake Albert Basin evolution can be subdivided into four major stages: a "pre-rifting" period and three "syn-rift" stages. Their characteristics are summarized on the Figure 10. 


\subsubsection{Pre-Rift (? to $\left.17.0 \pm 0.8 \mathrm{Ma}, \mathrm{S1}_{\mathrm{Un}}\right)$}

The first sediments are deposited on the weathering basement or filling incised "valley-like" structures (§4.4.2). The age and origin of these incisions are debated. Three scenarios can be proposed based on regional geological knowledge:

(1) Carboniferous to Early Permian (Karoo) glacial incisions filled by post-glacial lacustrine sediments (Ecca-type facies). This scenario is supported by numerous evidences of glacial valleys on the Congolese side of the EARS described by several authors (e.g. Cahen and Lepersonne, 1981; Linol et al., 2015) since the work of Boutakoff (1948), and by the occurrence of Early Permian glacio-lacustrine sediments north of Lake Victoria (Entebbe area; Schlueter et al., 1993). In this scenario, these glacial valleys were later faulted during the Triassic extension, a widespread episode of deformation well known in eastern and southern Africa (e.g. Catuneanu et al., 2005).

(2) A fluvial origin (bedrock channels) recording a pre-rift drainage flowing toward the Atlantic Ocean, as suggested by de Heinzelin (1962) and later by other authors (e.g. Pickford et al., 1993). The age of this network is not properly known but should be older than the Early Miocene and not the Pliocene as suggested by de Heinzelin (1962).

(3) Structures controlled by normal faults during the earliest stage of the rift as supported by the occurrence of the first extensional geometries $\left(S 1_{\mathrm{un}}-\mathrm{S} 2_{\mathrm{m}}\right)$ in the same area (south of Lake Albert).

The weathering profile (laterite) corresponds to kaolinitized basement rocks (5 to $20 \mathrm{~m}$ thick in several wells). These laterite profiles are well known on both sides of the rift and are related to African-scale climatic events (Beauvais et al., 2008; Burke and Gunnell, 2008; Chardon et al., 2006). They were first described in Uganda by Ollier (1960) and characterized at the Ugandan scale by McFarlane (1976) and Taylor and Howard (1998). On the Congolese side, they are dated as Paleocene - Early Eocene using cross-cutting relationships with the volcanic rocks of the Cameroon Volcanic Line (Guillocheau et al., 2015). These ages are consistent with the absolute dating performed in West- 
Africa by Beauvais et al. (2008). These weathering profiles are associated with humid periods recorded around the Early Eocene Climatic Optimum.

\subsubsection{Uppermost Early Miocene To Late Miocene (17.0 \pm 0.8 Ma to $6.2 \pm 0.2 \mathrm{Ma}$; $\mathrm{S1}_{\mathrm{Un}^{-}}$ $\left.\mathrm{S3}_{\mathrm{Un}}\right)$ : low extension phase}

The first sediments are preferentially located south of the Ngassa fault where up to $2300 \mathrm{~m}$ of accommodation space is created according to a mean rate of $150-250 \mathrm{~m} / \mathrm{Ma}$. In the early times (time interval $1 \mathrm{a} ; \mathrm{S} 1_{\mathrm{Un}}-\mathrm{S} 2_{\mathrm{m}}$ ), the accommodation is controlled by the fault in the southern Lake Albert Basin, as illustrated by the moderate thickness variations on each side of the major faults (e.g. Rwenzori fault; Figs. 8 \& 9).

The sedimentary infilling (cycles $\mathrm{C} 1, \mathrm{C} 2$ and transgressive half-cycle $\mathrm{C} 3$; Fig. 6) consists of lacustrine deposits (from distal "deep" facies to deltaic mouth bars and flood lobes), sometimes with fluvial deposits that are only observed on the Kaiso-Tonya flat and in the northern Butiaba (Fig. 8) and associated with the MRS. The $\mathrm{C} 2$ and $\mathrm{C} 3$ transgressive half cycles correspond to two major organic matter-rich lacustrine floodings (Fig. 6).

The main remaining questions are (1) the tectonic nature of the basin at this time (rift vs. flexural basin) and (2) its geographical extension compared to the present-day Lake Albert, with a larger lake at the time of deposition that later collapsed at the time of the true rifting.

(1) The main depocenter locations (Fig. 8, time interval 1) are not clearly controlled by the faults, suggesting a flexural deformation regime rather than a pure extension controlled by the major bounding faults. This is supported by the low accommodation rate during this time interval which ranges from $125 \mathrm{~m} / \mathrm{Ma}$ to no more than $250 \mathrm{~m} / \mathrm{Ma}$.

(2) The arguments for a larger basin extension than the present fault bounding the Lake Albert rift are:

- a northern large flexure, as stated above, suggesting a possibly larger basin than the present-day Lake Albert;

- the presence of lacustrine distal facies at the time of the major lake flooding close to the present-day bounding faults (Toro-Bunyoro fault, Figs. $2 \& 8$ ), along the Kaiso-Tonya flat 
(well 3 and well 4; Fig. 3), indicating a shoreline located beyond the present-day bounding faults;

- the absence of a true alluvial fan along the Kaiso-Tonya flat, close to the present-day border of the rift.

From a climatic point of view, this time interval records two humid periods, the second one corresponding to large-scale forest development recorded from Niger to East Africa and dated around 7 Ma (forest-phase; Bonnefille, 2010; Fig. 6).

These results question the age of the beginning of the sedimentary basin formation and of the initiation of the significant rifting. Previously, the rifting was considered as having initiated in the Uppermost Middle Miocene and Upper Miocene coeval with the initial Virunga volcanic episode (12.6 - 9 Ma, Kampunzu et al., 1998 and literature therein), following a "pre-rift" phase consisting of a shallow downwarp in Middle Miocene times (Pickford et al., 1993). Our work shows that sedimentation began as soon as the Uppermost Early Miocene (17.0 $\pm 0.8 \mathrm{Ma})$ in this downwarping (or flexure) which probably results from lithospheric stretching and thinning responsible for the local evidence of early and minor normal faulting observed in the infilling from the Uppermost Early Miocene $(17.0 \pm 0.8 \mathrm{Ma})$ to Late Miocene $(6.2 \pm 0.2 \mathrm{Ma})$.

4.5.3.Late Miocene To Lower Pleistocene (6.2 $\pm 0.2 \mathrm{Ma}$ to $\left.2.7 \pm 0.2 \mathrm{Ma} ; \mathrm{S3}_{\mathrm{Un}}-\mathrm{S4}_{\mathrm{Un} 2}\right)$ : first rifting phase

The transition with the previous interval coincides with a sharp basin-scale unconformity (surface $\mathrm{S} 3_{\mathrm{Un}}$ ). This time interval is characterized by a high accommodation rate (up to $800 \mathrm{~m} / \mathrm{Ma}$; Fig. 7 ) and the location of the main zones of subsidence are controlled by the faults (Fig. 8).

The sedimentary infilling (C3 regressive half-cycle and cycle C4; Fig. 6) mainly consists of distal shallow lacustrine facies passing laterally to deltaic and fluvial facies. Above the $S 4_{\mathrm{m}}$ flooding, the progradational trend results from an infilling of the basin by littoral (Fa4) to fluvial (Fa5) deposits, coeval with a sand enrichment and an increase in Poaceae pollens (Fig. 6). The unconformities (S4 Un1 and $\mathrm{S}_{\mathrm{Un} 2}$ ) are associated with the rapid disappearance of Pediastrum in favor of Poacea (Fig. 6). 
The remaining question is the nature of the deformation regime, pure extensional or oblique. Some authors have previously argued for such an oblique extension on the basis of possible splay geometries of a few faults (negative and positive flower structures; Abeinomugisha and Kasande, 2012) and the obliquity of Lake Albert in the framework of the western branch (e.g. Abeinomugisha, 2003; Abeinomugisha and Kasande, 2012; Abeinomugisha and Mugisha, 2004; Delvaux and Barth, 2010; Logan et al., 2009). Nevertheless, our seismic interpretations (Fig. 9) do not highlight either the existence of clear flower structures (when looking at the 1:1 exaggeration scale) or an en echelon fault pattern, thus making it difficult to come to a conclusion about a possible major strike-slip component.

The high subsidence rates $(600-800 \mathrm{~m} / \mathrm{Ma}$; Fig. 7) and the location of the depocenters down the major faults (Fig. 8) argue for a rifting phase. The lack of typical rift structures (e.g. growth strata and tilted blocks; Fig. 9) could be explained by the absence of shallow decollement levels.

\subsubsection{Lower Pleistocene $\left(2.7 \pm 0.2 \mathrm{Ma}, \mathrm{S4}_{\mathrm{Un} 2}\right)$ to Present Say: second rifting phase}

The transition to the last stage corresponds to a major unconformity $\left(\mathrm{S}_{\mathrm{Un} 2}\right)$. Sedimentation occurred along two major depocenters located to the north-west, between the Bunia and Butiaba faults and to the south-west, down the Rwenzori fault. The mean accommodation rates decrease from 400 to $200 \mathrm{~m} / \mathrm{Ma}$ (Fig. 8). The infilling (C5) is dominated by shallow lacustrine to fluvial deposits and the locations of the depocenters, combined with the subsidence rates, argue for a second rifting phase controlled by normal faults (Fig. 8).

The basal unconformity ( $\left(3_{\mathrm{Un} 2}\right)$ is related to the uplift of the Rwenzori Mountains and, probably, the Blue Mountains as indicated by:

(1) the field mapping and paleontological dating of the sedimentary succession of the KisegiNyabusosi area (Pickford et al., 1993), which indicates tilting and truncation at this time;

(2) the thermochronological data (Bauer et al., 2016, 2015, 2012, 2010a; MacPhee, 2006) showing a major exhumation phase for the Rwenzori Mountains at the Pliocene-Pleistocene interface;

(3) the occurrence of Podocarpus pollen which develop at an elevation higher than $1000 \mathrm{~m}$, confirming the growth of a close relief (i.e. the Rwenzori and Blue Mountains). 
These vertical movements are coeval with the uplift of the present-day flats (or terraces; e.g. KaisoTonya) bounded by the Butiaba and Toro-Bunyoro faults and the uplift and tilting of the northeastern part of the rift, the Butiaba area.

The $\mathrm{S} 4_{\mathrm{Un} 2}$ unconformity can also be correlated with a major phase of aridity that is well identified around 2.5 Ma (Bonnefille, 2010; Fig. 6).

During the Middle Pleistocene $(\approx 400 \mathrm{Ka})$, a second period of deformation and relief creation occurred with the flexuration of the Tanzanian craton in response to the uplift of both the western branch (Bauer et al., 2015, 2012, 2010a, 2010b) and eastern branch of the East African Rift System (Gregory Rift and North Tanzanian Divergence; Baker et al., 1978; Fairhead et al., 1972; Foster et al., 1997; Le Gall et al., 2008). This corresponds to a major drainage inversion and the creation of the Lake Victoria local base level (Pickford et al., 1993; Talbot and Williams, 2009; Taylor and Howard, 1998; Williams et al., 2003). This could be the growth period for the present-day Ugandan escarpment of the Albert Rift with reactivation of the Toro-Bunyoro and Tonya bounding faults, as suggested by the perched incised valleys observed at the top of the scarp.

\section{DISCUSSION}

The question here is whether to discuss the local- or EARS-scale meaning of the periods of deformation pattern changes in the Lake Albert Basin around 17.0, 6.2 and 2.7 Ma. From this perspective, we have summarized the evolution of the different basins in the EARS based on the tremendous amount of publications that have focused, per basin, on (1) the dated volcanism, (2) the sedimentary succession, (3) the known unconformities recording changes of deformation and (4) the denudation periods provided by the thermochronological data (Fig. 11). Unfortunately, no absolute ages are available for two major non volcanic rifts, the Tanganyika and Malawi Rifts.

\subsection{UPPERMOST EARLY MIOCENE (17.0 Ma)}

The first period dated at 17.0 Ma (late Early Miocene), i.e. initiation of the subsidence in the Lake Albert Basin - low and diffuse extension), is recorded on the northern part of the East African Dome along the eastern branch of the EARS in central and southern Kenya and in the Anza Rift. This is not 
the case in the northern Kenya rifts (Turkana s.l.), on the gap between the Ethiopian and East African Domes, where it is not recognized.

In the Anza Rift (Morley et al., 1999a), this corresponds to the end of the subsidence of the basin under a strike-slip tectonic regime characterized by a major unconformity and the last marine flooding in the area.

In central Kenya (South-Kerio and Baringo-Bongoria basins), the Uppermost Early Miocene is associated with the end of a first depositional period of unknown age which possibly filled a first graben (Kimwarer and Kamego Formations; e.g. Chapman and Brook, 1978; Hautot et al., 2000; Tiercelin et al., 2012) overlapped by volcanics (Elgayo and Samburu basalt, Uasin-Gishu, Sidekh and Tim phonolites) onlapping both sides of the previous early sedimentary basin with a clear flexural pattern (Baker, 1987; Chapman and Brook, 1978; Hautot et al., 2000; Mugisha et al., 1997). This period is also coeval with the first occurrence of volcanism (Kishalduga nephelinites; $\approx 16 \mathrm{Ma}$ ) in southern Kenya, in the area of the Upper Miocene Gregory Rift (Crossley, 1979; Crossley and Knight, 1981).

\subsection{LATE MIOCENE (6.2 Ma)}

The initiation of significant rifting at 6.2 Ma (Late Miocene) in the Lake Albert Basin (Rift stage 1) can be related to a set of deformation events ranging from 7.5 to $6 \mathrm{Ma}$ (with a lot of dating uncertainties) on the East African Dome, from the northern Kenya basins to the northern Tanzania basins, along the eastern branch and up to the Rukwa Rift in the central part the western branch.

In the northern Kenya basins, this period corresponds to the beginning of the outpouring of the Gombe Basalt which follows a hiatus of $6 \mathrm{Ma}$ in both the volcanic and sedimentation record in the Koobi Fora Sub-basin (Nabwal Hills; north-east of the present-day Turkana Rift; McDougall and Watkins, 2006, 1988). This can also be the age of the discontinuity between the Nawata and Nachukui formations in the Lothagam area (south-west of the present-day Turkana Rift; McDougall and Feibel, 1999). In the central Kenyan Rifts, this period of deformation could be recorded by the unconformity occurring at the base of the Kabernet Trachyte in the Tugen hills (Chapman et al., 1978; Chapman and Brook, 
1978). In the Rukwa Rift, the Late Miocene could correspond to the beginning of a second period of rifting (Morley et al., 1999b; Roberts et al., 2012, 2010; Wescott et al., 1991).

In central Kenya, thermochronological data indicates the denudation and uplift of the rift flanks between 7 and $4 \mathrm{Ma}$ on the eastern side and between 5 and 2 on the western side (Spiegel et al., 2007).

\subsection{PLIOCENE-PLEISTOCENE TRANSITION (2.7 Ma)}

The change in rifting mode in the Albert Rift recorded at 2.7 Ma (Pliocene-Pleistocene transition; coeval with the uplift of the Rwenzori Mountains), is not easy to relate to one precise deformation event occurring along the East African Dome because of the several tectonics pulse (and associated unconformities) and deformation pattern changes recorded in both the western and eastern branches.

It could be related to the reactivation of the rifing in the Baringo-Bongoria Rift in central Kenya (Chapman and Brook, 1978; Hautot et al., 2000; Le Gall et al., 2000; Morley et al., 1992) or to the different stages of extension recorded in the basins of the North Tanzanian Divergence (2.5 and 1.5 Ma, Natron, Manyara and Eyasi Basins; Foster et al., 1997; Le Gall et al., 2008)

Taking into account an error bar of $\approx 1 \mathrm{Ma}$, the main unconformities of the Lake Albert Basin seem to occur at the East African Dome scale, even if, at this moment, it is impossible to infer and characterize the regional deformation changes at the time of these unconformities. A second interesting result is that the basins of both branches experienced the same geometrical evolution from large basins with limited fault controls during the Late Miocene to narrow true rifting in the Late Pleistocene (northern Kenya basins: Evans, 2013; Central Kenya Basins: e.g. Chapman et al., 1978), in agreement with the volcanism distribution, which was large (width $>100 \mathrm{~km}$ ) during Miocene times, narrower (width $\mathrm{x}$ $10 \mathrm{~km}$ ) from Late Pliocene to Pleistocene times and is today limited to narrow rifts (Baker and Wohlenberg, 1971). 


\section{CONCLUSIONS}

In the present work, we have proposed a new reconstruction of the tectono-sedimentary evolution of the Lake Albert Basin based on a re-evaluation of the outcropping data (sedimentary facies and biostratigraphic data) and on an exceptional subsurface dataset. We were able to:

- carry out the first sequence stratigraphic framework for one of the East African Rifts (the Lake Albert Rift) defining the major stratigraphic surfaces (maximum flooding and unconformities) and cycles on the basis of outcrops, well-logs (stacking pattern) and pollen/spore trend (proxy of the lake level variations) correlations,

- propose an age model based on the onshore mammals biozones propagated at the basin-scale by onshore - offshore correlations and climatostratigraphy (palynology and sequence stratigraphy),

- quantify the accommodation (as a proxy of subsidence) evolution though time using all of the previously mentioned data.

On the basis of biostratigraphical studies, early deposition in the Lake Albert Basin occurred during Early Miocene times (17.0 Ma), much older than the Late Miocene age previously considered on the basis of volcanic events and old biostratigraphical ages.

The infilling essentially consists of lacustrine deposits wherein two major unconformities dated at 6.2 Ma (Uppermost Miocene) and 2.7 Ma (Pliocene-Pleistocene boundary) were characterized, coeval with major subsidence and climatic changes.

Combined with the fault analysis, the evolution of the subsidence and its distribution highlight a four-step evolution of the Lake Albert Basin:

- Incision of the basement of unknown origin and age but prior to the Early Miocene.

- $\quad 17.0$ to $6.2 \mathrm{Ma}$ : the flexural basin was potentially larger than the present-day rift and was infilled by organic-rich lacustrine deposits. 
- 6.2 to 2.5 Ma: first phase of rifting characterized by high subsidence rates in depocenters controlled by the fault.

- 2.5 to 0 Ma: a second rifting phase following the uplift of the Rwenzori Mountains and, potentially, the Blue Mountains. The locations of the depocenters are controlled by the major faults and predominantly located in the central and southern part of the basin.

The specificity of the Lake Albert Basin is its geometrical configuration. Actually, it consists of isopach fault-bounded units with no clear characteristics of a rift (i.e. tilted blocks, growth strata) but with relatively high subsidence rates, possibly suggesting low extension rates and a lack of a shallow decollement level.

\section{ACKNOWLEGMENTS}

We gratefully acknowledge current and former Total colleagues for their contributions to the global database used in this study. We are also grateful to Dr. Sara Mullin for post-editing the English and to the two reviewers for their constructive comments.

\section{FUNDINGS}

This work was supported by the Total company (Centre scientifique et technique Jean Feger, Pau, France). 


\section{REFERENCES}

Abeinomugisha, D., 2003. Structural styles in the Albertine Graben, in: Unpublished Report. Ugandan Petroleum Exploration and Production Department.

Abeinomugisha, D., Kasande, R., 2012. Tectonic control on hydrocarbon accumulation in the intracontinental Albertine Graben of the East African Rift System, in: Gao, D. (Ed.), Tectonics and Sedimentation: Implications for Petroleum Systems. AAPG Memoir 100, pp. 209-228. doi:10.1306/13351554M1003539

Abeinomugisha, D., Mugisha, F., 2004. Structural analysis of the Albertine graben, Western Uganda, in: Abstract, East African Rift System Evolution, Resources and Environmental Conference, Addis Abeba.

Adam, W., Lepersonne, J., 1959. Mollusques pléistocènes de la région du Lac Albert et de la Semliki, in: Annales Du Musée Royal de l’Afrique Centrale. Musée Royal du Congo Belge, pp. 1-159.

Allen, J.R.L., 1965. A review of the origin and characteristics of recent alluvial sediments. Sedimentology 5, 89-191.

Allen, P.A., 1981. Devonian lake margin environments and processes, SE Shetland, Scotland. J. Geol. Soc. London. 138, 1-14.

Baker, B.H., 1987. Outline of the petrology of the Kenya rift alkaline province. Geol. Soc. London, Spec. Publ. 30, 293-311.

Baker, B.H., Crossley, R., Goles, G.G., 1978. Tectonic and magmatic evolution of the southern part of the Kenya rift valley, in: Petrology and Geochemistry of Continental Rifts. Springer Netherlands, pp. 29-59.

Baker, B.H., Williams, L.A.J., Miller, J.A., Fitch, F.J., 1971. Sequence and geochronology of the Kenya rift volcanics. Tectonophysics 11, 191-215.

Baker, B.H.T., Wohlenberg, J., 1971. Structure and evolution of the Kenya Rift Valley. Nature 229, $538-542$.

Bauer, F., Glasmacher, U., Ring, U., Grobe, R., Mambo, V., Starz, M., 2016. Long-term cooling history of the Albertine Rift: new evidence from the western rift shoulder, D.R. Congo. Int. J. Earth Sci. 105, 1707-1728.

Bauer, F.U., Glasmacher, U.A., Ring, U., Grobe, R.W., Mambo, V.S., Starz, M., 2015. Long-term cooling history of the Albertine Rift: new evidence from the western rift shoulder, DR Congo. Int. J. Earth Sci. 104, 1-22.

Bauer, F.U., Glasmacher, U.A., Ring, U., Schumann, A., Nagudi, B., 2010a. Thermal and exhumation history of the central Rwenzori Mountains, Western Rift of the East African Rift System, Uganda. Int. J. Earth Sci. 99, 1575-1597. doi:10.1007/s00531-010-0549-7

Bauer, F.U., Karl, M., Glasmacher, U.A., Nagudi, B., Schumann, A., Mroszewski, L., 2012. The Rwenzori Mountains of western Uganda - Aspects on the evolution of their remarkable morphology within the Albertine Rift. J. African Earth Sci. 73, 44-56. doi:10.1016/j.jafrearsci.2012.07.001

Bauer, F.U., Koehn, D., Glasmacher, U. a., 2010b. Long-term rift evolution. Int. J. Earth Sci. 99, 1483-1485. doi:10.1007/s00531-010-0601-7

Beauvais, A., Ruffet, G., Hénocque, O., Colin, F., 2008. Chemical and physical erosion rhythms of the West African Cenozoic morphogenesis: The 39Ar-40Ar dating of supergene K-Mn oxides. J. Geophys. Res. Earth Surf. 113, (F4).

Bellon, H., Pouclet, A., 1980. Datations K-Ar de quelques laves du Rift-Ouest de l'Afrique Centrale; implications sur l'évolution magmatique et structurale. Geol. Rundschau 69, 49-62. 
Bishop, W.W., 1971. The late Cenozoic history of East Africa in relation to hominoid evolution, The Late Cenozoic Glacial Ages. Yale University Press New Haven.

Bishop, W.W., 1965. Quaternary geology and geomorphology in the Albertine Rift Valley, Uganda. Geol. Soc. Am. Spec. Pap. 84, 293-322.

Bishop, W.W., Miller, J.A., Fitch, F.J., 1969. New potassium-argon age determinations relevant to the Miocene fossil mammal sequence in East Africa. Am. J. Sci. 267, 669-699.

Bonnefille, R., 2010. Cenozoic vegetation, climate changes and hominid evolution in tropical Africa. Glob. Planet. Change 72, 390-411.

Bosworth, W., 1985. Discussion on the structural evolution of extensional basin margins. J. Geol. Soc. London. 142, 939-942. doi:10.1144/gsjgs.142.5.0939

Boutakoff, N., 1948. Les formations glaciaires et postglaciaires fossilifères, d'âge permo-carbonifère (Karroo inférieur) de la région de Walikale (Kivu, Congo Belge). Mem. l'Institut Geol. l’Universite Louvain 9, 124 p.

Burke, K., 1996. The African plate. South african J. Geol. 99, 341-409.

Burke, K., Gunnell, Y., 2008. The African erosion surface: a continental-scale synthesis of geomorphology, tectonics, and environmental change over the past 180 million years. Geol. Soc. Am. Mem. 201, 1-66.

Cahen, L., Lepersonne, J., 1981. Proterozoic diamictites of lower Zaire, in: Hambrey, M.J., Harland, W.B. (Eds.), Earth's Pre-Pleistocene Glacial Record. Cambridge University Press, pp. 153-157.

Calais, E., Ebinger, C.J., Hartnady, C., Nocquet, J.M., 2006. Kinematics of the East African Rift from GPS and earthquake slip vector data. Geol. Soc. London, Spec. Publ. 259, 9-22. doi:10.1144/GSL.SP.2006.259.01.03

Catuneanu, O., Abreu, V., Bhattacharya, J.P., Blum, M.D., Dalrymple, R.W., Eriksson, P.G., Fielding, C.R., Fisher, W.L., Galloway, W.E., Gibling, M.R., 2009. Towards the standardization of sequence stratigraphy. Earth-Science Rev. 92, 1-33.

Catuneanu, O., Wopfner, H., Eriksson, P.G., Cairncross, B., Rubidge, B.S., Smith, R.M.H., Hancox, P.J., 2005. The Karoo basins of south-central Africa. J. African Earth Sci. 43, 211-253.

Chapman, G.R., Brook, M., 1978. Chronostratigraphy of the Baringo basin, Kenya. Geol. Soc. London, Spec. Publ. 6, 207-223.

Chapman, G.R., Lippard, S.J., Martyn, J.E., 1978. The stratigraphy and structure of the Kamasia range, Kenya Rift Valley. J. Geol. Soc. London. 135, 265-281.

Chardon, D., Chevillotte, V., Beauvais, A., Grandin, G., Boulangé, B., 2006. Planation, bauxites and epeirogeny: One or two paleosurfaces on the West African margin? Geomorphology 82, 273 282.

Chorowicz, J., 2005. The East African rift system. J. African Earth Sci. 43, 379-410. doi:10.1016/j.jafrearsci.2005.07.019

Chorowicz, J., 1990. Dynamics of the different basin-types in the East African rift. J. African Earth Sci. (and Middle East) 10, 271-282. doi:http://dx.doi.org/10.1016/0899-5362(90)90060-R

Chorowicz, J., Mukonki, M.B., 1980. Apport géologique des images MSS Landsat du secteur autour du lac Kivu (Burundi, Rwanda, Zaire). Comptes Rendus l'Academie des Sci. 290, 1245-1247.

Chorowicz, J., Sorlien, C., 1992. Oblique extensional tectonics in the Malawi Rift, Africa. Geol. Soc. Am. Bull. 104, 1015-1023.

Coleman, J.M., Wright, L.D., 1975. Modern river deltas: variability of processes and sand bodies, in: Deltas, Models for Exploration. Houston Geological Society, Houston, Texas, pp. 99-150. 
Cooke, H.B.S., Coryndon, S.C., 1970. Pleistocene mammals from the Kaiso Formation and other related deposits in Uganda. Foss. Vertebr. Africa 2, 107-224.

Corti, G., Van Wijk, J., Cloetingh, S., Morley, C.K., 2007. Tectonic inheritance and continental rift architecture: Numerical and analogue models of the East African Rift system. Tectonics 26, 113.

Crossley, R., 1979. The Cenozoic stratigraphy and structure of the western part of the rift valley in southern Kenya. J. Geol. Soc. London. 136, 393-405.

Crossley, R., Knight, R.M., 1981. Volcanism in the western part of the rift valley in southern Kenya. Bull. Volcanol. 44, 117-128.

Daly, M.C., Chorowicz, J., Fairhead, J.D., 1989. Rift basin evolution in Africa: the influence of reactivated steep basement shear zones, in: Cooper, M.A., Williams, G.D. (Eds.), Inversion Tectonics. Geological Society of London Special Publications, pp. 309-334.

de Heinzelin, J., 1959. Les formations du Western Rift et de la cuvette Congolaise. Actes IVe Congrès Panafricain Prehistoire, section I. Ann. du Musée R. L'afrique Cent. Sci. Hum. 40, 219-243.

Delvaux, D., 2001. Tectonic and palaeostress evolution of the Tanganyika-Rukwa-Malawi rift segment, East African rift System. Peri-Tethys Mem. 6, 545-567.

Delvaux, D., Barth, A., 2010. African stress pattern from formal inversion of focal mechanism data. Tectonophysics 482, 105-128. doi:10.1016/j.tecto.2009.05.009

Ebinger, C.J., 1989a. Tectonic development of the western branch of the East African rift system. Geol. Soc. Am. Bull. 101, 885-903.

Ebinger, C.J., 1989b. Geometric and kinematic development of border faults and accommodation zones, Kivu-Rusizi rift, Africa. Tectonics 8, 117-133.

Ebinger, C.J., Karner, G.D., Weissel, J.K., 1991. Mechanical strength of extended continental lithosphere: Constraints from the Western Rift System, East Africa. Tectonics 10, 1239-1256. doi:10.1029/91TC00579

Ebinger, C.J., Sleep, N.H., 1998. Cenozoic magmatism throughout east Africa resulting from impact of a single plume. Nature $395,788-791$.

Embry, A.F., 2009. Practical sequence stratigraphy. Canadian Society of Petroleum Geologists.

Fairhead, J.D., Mitchell, J.G., Williams, L.A.J., 1972. New K/Ar determinations on rift volcanics of S. Kenya and their bearing on age of rift faulting. Nature 238, 66-69.

Foster, A., Ebinger, C.J., Mbede, E., Rex, D., 1997. Tectonic development of the northern Tanzanian sector of the East African Rift System. J. Geol. Soc. London. 154, 689-700.

Galloway, W.E., 2001. Cenozoic evolution of sediment accumulation in deltaic and shore-zone depositional systems, northern Gulf of Mexico Basin. Mar. Pet. Geol. 18, 1031-1040.

Gautier, A., 1965. Relative dating of peneplains and sediments in the Lake Albert Rift area. Am. J. Sci. 263, 537-547.

George, R., Rogers, N., Kelley, S., 1998. Earliest magmatism in Ethiopia: evidence for two mantle plumes in one flood basalt province. Geology 26, 923-926.

Gradstein, F.M., Ogg, J.G., Schmitz, M., Ogg, G., 2012. The Geologic Time Scale 2012. Elsevier.

Guillocheau, F., Chelalou, R., Linol, B., Dauteuil, O., Robin, C., Mvondo, F., Callec, Y., Colin, J.-P., 2015. Cenozoic Landscape Evolution in and Around the Congo Basin: Constraints from Sediments and Planation Surfaces, in: de Wit, M.J., Guillocheau, F., de Wit, M.C.J. (Eds.), Geology and Resource Potential of the Congo Basin. Springer, pp. 271-314.

Hautot, S., Tarits, P., Whaler, K., Le Gall, B., Tiercelin, J.J., Le Turdu, C., 2000. Deep structure of the 
Baringo Rift Basin (central Kenya) from three dimensional magnetotelluric imaging: Implications for rift evolution. J. Geophys. Res. Solid Earth 105, 23493-23518.

Helland-Hansen, W., Martinsen, O.J., 1996. Shoreline trajectories and sequences; description of variable depositional-dip scenarios. J. Sediment. Res. 66, 670-688. doi:10.1306/D42683DD2B26-11D7-8648000102C1865D

Homewood, P., Guillocheau, F., Eschard, R., Cross, T.A., 1992. Corrélations haute résolution et stratigraphie génétique: une démarche intégrée. Bull. des Centres Rech. Explor. Elf-Aquitaine $16,357-381$.

Homuth, B., Löbl, U., Batte, A., Link, K., Kasereka, C., Rümpker, G., 2016. Seismic anisotropy of the lithosphere/asthenosphere system beneath the Rwenzori region of the Albertine Rift. Int. J. Earth Sci. 105, 1681-1692.

Hooijer, D.A., Gautier, A., Lepersonne, J., 1963. Miocene mammalia of Congo. Ann. du Musée R. l'Afrique Cent. 46, 1-71.

Hopwood, A.T., 1926. Fossil mammalia. Geol. Palaeontol. Kaiso Bone Beds. Occas. Pap. Geol. Surv. Uganda 2, 13-36.

Hopwood, A.T., Lepersonne, J., 1953. Présence de formations d'âge Miocène inférieur dans le fossé tectonique du lac Albert et de la Basse Semliki (Congo Belge). Ann. la Société Géologique Belgique 77, 83-113.

Howard, K.W.F., Karundu, J., 1992. Constraints on the exploitation of basement aquifers in East Africa - water balance implications and the role of the regolith. J. Hydrol. 139, 183-196.

Kampunzu, A.B., Bonhomme, M.G., Kanika, M., 1998. Geochronology of volcanic rocks and evolution of the Cenozoic Western Branch of the East African Rift System. J. African Earth Sci. 26, 441-461.

Kampunzu, A.B., Kapenda, D., Manteka, B., 1991. Basic magmatism and geotectonic evolution of the Pan African belt in Central Africa: evidence from the Katangan and West Congolian segments. Tectonophysics 190, 363-371.

Karner, G.D., Byamungu, B.R., Ebinger, C.J., Kampunzu, A.B., Mukasa, R.K., Nyakaana, J., Rubondo, E.N.T., Upcott, N.M., 2000. Distribution of crustal extension and regional basin architecture of the Albertine rift system, East Africa. Mar. Pet. Geol. 17, 1131-1150.

Karp, T., Scholz, C.A., Mcglue, M.M., 2012. Structure and stra. doi:10.1306/13291394M952903

Kazmin, V., 1980. Transform faults in the East African rift system, in: Geodynamic Evolution of the Afro-Arabian Rift System. Roma Accademia Nazionale dei Lincei (Atti dei Convegni Lincei 47), pp. 65-73.

Koehn, D., Lindenfeld, M., Rümpker, G., Aanyu, K., Haines, S., Passchier, C.W., Sachau, T., 2010. Active transsection faults in rift transfer zones: evidence for complex stress fields and implications for crustal fragmentation processes in the western branch of the East African Rift. Int. J. Earth Sci. 99, 1633-1642. doi:10.1007/s00531-010-0525-2

Koehn, D., Link, K., Sachau, T., Passchier, C., Aanyu, K., Spikings, A., Harbinson, R., 2016. The Rwenzori Mountains, a Palaeoproterozoic crustal shear belt crossing the Albertine rift system. Int. J. Earth Sci. 105, 1693-1705.

Kusznir, N.J., Ziegler, P.A., 1992. The mechanics of continental extension and sedimentary basin formation: a simple-shear/pure-shear flexural cantilever model. Tectonophysics 215, 117-131.

Le Gall, B., Nonnotte, P., Rolet, J., Benoit, M., Guillou, H., Mousseau-Nonnotte, M., Albaric, J., Deverchère, J., 2008. Rift propagation at craton margin : Distribution of faulting and volcanism in the North Tanzanian Divergence (East Africa) during Neogene times. Tectonophysics 448, $1-$ 19. 
Le Gall, B., Tiercelin, J.J., Richert, J.P., Gente, P., Sturchio, N.C., Stead, D., Le Turdu, C., 2000. A morphotectonic study of an extensional fault zone in a magma-rich rift: the Baringo Trachyte Fault System, central Kenya Rift. Tectonophysics 320, 87-106. doi:10.1016/S00401951(00)00069-X

Lepersonne, J., 1949. Le fossé tectonique Lac Albert-Semliki-Lac Edouard. Ann. la Société Géologique Belgique 62, 1-92.

Lezzar, K.E., Tiercelin, J.J., Le Turdu, C., Cohen, A.S., Reynolds, D.J., Le Gall, B., Scholz, C.A., 2002. Control of normal fault interaction on the distribution of major Neogene sedimentary depocenters, Lake Tanganyika, East African rift. Am. Assoc. Pet. Geol. Bull. 86, 1027-1060.

Linol, B., de Wit, M.J., Guillocheau, F., Robin, C., Dauteuil, O., 2015. Multiphase Phanerozoic Subsidence and Uplift History Recorded in the Congo Basin: A Complex Successor Basin, in: Geology and Resource Potential of the Congo Basin. Springer, pp. 213-227.

Logan, P., Curd, S., Downie, B., Weston, J., Shaw, D., 2009. Exploration on the Frontier: Towards an Understanding of the Albert Basin. Am. Assoc. Pet. Geol. Search Discov. Artic. 10192.

Lukaye, J.M., 2009. Biostratigraphy and Palynofacies of Four Exploration Wells from the Abertine Graben - Uganda. Am. Assoc. Pet. Geol. Search Discov. Artic. 50169.

MacInnes, D.G., 1942. Miocene and Post-Miocene Proboscidea from East Africa. Trans. Zool. Soc. London 25, 33-106.

MacPhee, D., 2006. Exhumation, rift-flank uplift, and the thermal evolution of the Rwenzori Mountains determined by combined (U-Th)/He and U-Pb thermochronometry (Master Thesis). Master Thesis. Massachusetts Institute of Technology.

McConnell, R.B., 1959. Outline of the geology of the Ruwenzori Mountains: a preliminary account of the esults of the British Ruwenzori Expedition, 1951-1952. Overseas Geol. Miner. Resour. 7, $245-268$.

McDougall, I., Brown, F.H., 2009. Timing of volcanism and evolution of the northern Kenya Rift. Geol. Mag. 146, 34-47.

McDougall, I., Feibel, C.S., 1999. Numerical age control for the Miocene-Pliocene succession at Lothagam, a hominoid-bearing sequence in the northern Kenya Rift. J. Geol. Soc. London. 156, 731-745.

McDougall, I., Watkins, R.T., 2006. Geochronology of the Nabwal Hills: a record of earliest magmatism in the northern Kenyan Rift Valley. Geol. Mag. 143, 25-39.

McDougall, I., Watkins, R.T., 1988. Potassium - argon ages of volcanic rocks from northeast of Lake Turkana, northern Kenya. Geol. Mag. 125, 15-23.

McFarlane, M.J., 1976. Laterite and the Denudation Chronology of Uganda, in: McFarlane, M.J. (Ed.), Laterite and Landscape. Academic Press, pp. 109-140.

McGregor, D., 2015. History of the development of the East African Rift System: A series of interpreted maps through time. J. African Earth Sci. 101, 232-252. doi:http://dx.doi.org/10.1016/j.jafrearsci.2014.09.016

Miall, A.D., 2006. The geology of fluvial deposits; sedimentary facies, basin analysis, and petroleum geology. 4th Edition. Springer Verlag.

Morley, C.K., 2010. Stress re-orientation along zones of weak fabrics in rifts: An explanation for pure extension in "oblique" rift segments? Earth Planet. Sci. Lett. 297, 667-673.

Morley, C.K., 1999. Aspects of Transfer Zone Geometry and Evolution in East African Rifts, in: Morley, C.K. (Ed.), Geoscience of Rift Systems - Evolution of East Africa. AAPG Studies in Geology \#44, pp. 161-171. 
Morley, C.K., Bosworth, W., Day, R.A., Lauck, R., Bosher, R., Stone, D.M., Wigger, S.T., Wescott, W.A., Haun, D., Bassett, N., 1999a. Geology and Geophysics of the Anza Graben, in: Morley, C.K. (Ed.), Geoscience of Rift Systems - Evolution of East Africa. AAPG Studies in Geology 44, pp. 67-90.

Morley, C.K., Cunningham, S.M., Wescott, W.A., Harper, R.M., 1999b. Geology and Geophysics of the Rukwa Rift, in: Morley, C.K. (Ed.), Geoscience of Rift Systems - Evolution of East Africa. AAPG Studies in Geology \#44, pp. 91-110.

Morley, C.K., Karanja, F.M., Wescott, W.A., Stone, D.M., Harper, R.M., Wigger, S.T., Day, R.A., 1999c. Geology and Geophysics of the Western Turkana Basins, Kenya, in: Morley, C.K. (Ed.), Geoscience of Rift Systems - Evolution of East Africa. AAPG Studies in Geology \#44, pp. 1954.

Morley, C.K., Wescott, W.A., Stone, D.M., Harper, R.M., Wigger, S.T., Karanja, F.M., 1992. Tectonic evolution of the northern Kenyan Rift. J. Geol. Soc. London. 149, 333-348.

Mugisha, F., Ebinger, C.J., Strecker, M., Pope, D., 1997. Two-stage rifting in the Kenya rift: implications for half-graben models. Tectonophysics 278, 63-81.

Mutti, E., Tinterri, R., Di Biase, D., Fava, L., Mavilla, N., Angella, S., Calabrese, L., 2000. Delta-front facies associations of ancient flood-dominated fluvio-deltaic systems. Rev. la Soc. Geológica España 13, 165-190.

Nyblade, A.A., Brazier, R.A., 2002. Precambrian lithospheric controls on the development of the East African rift system. Geology 30, 755. doi:10.1130/00917613(2002)030<0755:PLCOTD >2.0.CO;2

Nyblade, A.A., Robinson, S.W., 1994. The African superswell. Geophys. Res. Lett. 21, 765-768.

Olariu, C., Bhattacharya, J.P., Leybourne, M.I., Boss, S.K., Stern, R.J., 2012. Interplay between river discharge and topography of the basin floor in a hyperpycnal lacustrine delta. Sedimentology 59, 704-728.

Olariu, C., Steel, R.J., 2009. Influence of point-source sediment-supply on modern shelf-slope morphology: implications for interpretation of ancient shelf margins. Basin Res. 21, 484-501.

Olariu, C., Steel, R.J., Petter, A.L., 2010. Delta-front hyperpycnal bed geometry and implications for reservoir modeling: Cretaceous Panther Tongue delta, Book Cliffs, Utah. Am. Assoc. Pet. Geol. Bull. 94, 819-845.

Ollier, C.D., 1960. The inselbergs of Uganda. Zeitschrift für Geomorphol. 4, 43-52.

Pickford, M., Senut, B., Hadoto, D.P.M., 1993. Geology and Palaeobiology of the Albertine Rift Valley, Uganda-Zaire: Geology. Cent. Int. pour la Form. les Echanges Geol. 24, 1-1989.

Pik, R., Marty, B., Carignan, J., Lavé, J., 2003. Stability of the Upper Nile drainage network (Ethiopia) deduced from (U-Th)/He thermochronometry: implications for uplift and erosion of the Afar plume dome. Earth Planet. Sci. Lett. 215, 73-88.

Pik, R., Marty, B., Hilton, D.R., 2006. How many mantle plumes in Africa? The geochemical point of view. Chem. Geol. 226, 100-114.

Posamentier, H.W., Allen, G.P., 1997. Siliciclastic sequence stratigraphy: concepts and applications. Concepts Sedimentol. Paleontol. 7, 1-204.

Pouclet, A., Bellon, H., Bram, K., 2016. The Cenozoic volcanism in the Kivu rift: Assessment of the tectonic setting, geochemistry, and geochronology of the volcanic activity in the South-Kivu and Virunga regions. J. African Earth Sci. 121, 219-246. doi:10.1016/j.jafrearsci.2016.05.026

Ring, U., 2008. Extreme uplift of the Rwenzori Mountains in the East African Rift, Uganda: Structural framework and possible role of glaciations. Tectonics 27, 1-19. doi:10.1029/2007TC002176 
Ritsema, J., Nyblade, A.A., Owens, T.J., Langston, C. a., VanDecar, J.C., 1998. Upper mantle seismic velocity structure beneath Tanzania, east Africa: Implications for the stability of cratonic lithosphere. J. Geophys. Res. 103, 21201-21213. doi:10.1029/98JB01274

Roberts, E.M., O’Connor, P.M., Stevens, N.J., Gottfried, M.D., Jinnah, Z.A., Ngasala, S., Choh, A.M., Armstrong, R.A., 2010. Sedimentology and depositional environments of the Red Sandstone Group, Rukwa Rift Basin, southwestern Tanzania: New insight into Cretaceous and Paleogene terrestrial ecosystems and tectonics in sub-equatorial Africa. J. African Earth Sci. 57, 179-212. doi:http://dx.doi.org/10.1016/j.jafrearsci.2009.09.002

Roberts, E.M., Stevens, N.J., O’Connor, P.M., Dirks, P.H.G.M., Gottfried, M.D., Clyde, W.C., Armstrong, R. a., Kemp, a. I.S., Hemming, S., 2012. Initiation of the western branch of the East African Rift coeval with the eastern branch. Nat. Geosci. 5, 289-294. doi:10.1038/ngeo1432

Rosendahl, B.R., 1987. Architecture of continental rifts with special reference to East Africa. Annu. Rev. Earth Planet. Sci. 15, 445.

Sachau, T., Koehn, D., Stamps, D., Lindenfeld, M., 2016. Fault kinematics and stress fields in the Rwenzori Mountains, Uganda. Int. J. Earth Sci. 105, 1729-1740.

Saria, E., Calais, E., Altamimi, Z., Willis, P., Farah, H., 2013. A new velocity field for Africa from combined GPS and DORIS space geodetic Solutions: Contribution to the definition of the African reference frame (AFREF). J. Geophys. Res. Solid Earth 118, 1677-1697. doi:10.1002/jgrb.50137

Saria, E., Calais, E., Stamps, D.S., Delvaux, D., Hartnady, C.. J.H., 2014. Present-day kinematics of the East African Rift. J. Geophys. Res. Solid Earth 119, 3584-3600.

Schlueter, T., Pico-Olarker, G., Kreuser, T., 1993. A review of some neglected Karoo grabens of Uganda. J. African Earth Sci. (and Middle East) 17, 415-428.

Scott, D.L., Rosendahl, B.R., 1989. North Viking graben: an east African perspective. Am. Assoc. Pet. Geol. Bull. 73, 155-165.

Shaw, D., Logan, P.C., Weston, J., 2009. A Palynological Study of Neogene and Holocene Sediments from Lake Albert, Uganda, with Implications for Vegetation and Climatic Changes in East Africa. Am. Assoc. Pet. Geol. Search Discov. Artic. 50180.

Simmons, N.A., Forte, A.M., Grand, S.P., 2007. Thermochemical structure and dynamics of the African superplume. Geophys. Res. Lett. 34.

Spiegel, C., Kohn, B.P., Belton, D.X., Gleadow, A.J.W., 2007. Morphotectonic evolution of the central Kenya rift flanks: Implications for late Cenozoic environmental change in East Africa. Geology 35, 427-430.

Stamps, D.S., Calais, E., Saria, E., Hartnady, C., Nocquet, J.-M., Ebinger, C.J., Fernandes, R.M., 2008. A kinematic model for the East African Rift. Geophys. Res. Lett. 35, L05304. doi:10.1029/2007GL032781

Stamps, D.S., Flesch, L.M., Calais, E., Ghosh, A., 2014. Current kinematics and dynamics of Africa and the East African Rift System. J. Geophys. Res. Solid Earth 119, 5161-5186.

Talbot, M.R., Williams, M.A.J., 2009. Cenozoic Evolution of the Nile Basin, in: Dumont, H.J. (Ed.), The Nile: Origin, Environments, Limnology and Human Use. Springer Netherlands, pp. 37-60.

Taylor, R.G., Howard, K.W.F., 1999. The influence of tectonic setting on the hydrological characteristics of deeply weathered terrains: evidence from Uganda. J. Hydrol. 218, 44-71. doi:10.1016/S0022-1694(99)00024-4

Taylor, R.G., Howard, K.W.F., 1998. Post-Palaeozoic evolution of weathered landsurfaces in Uganda by tectonically controlled deep weathering and stripping. Geomorphology 25, 173-192. 
Tiercelin, J.J., Chorowicz, J., Bellon, H., Richert, J.P., Mwanbene, J.T., Walgenwitz, F., 1988. East African rift system: offset, age and tectonic significance of the Tanganyika-Rukwa-Malawi intracontinental transcurrent fault zone. Tectonophysics 148, 241-252. doi:http://dx.doi.org/10.1016/0040-1951(88)90133-3

Tiercelin, J.J., Potdevin, J.L., Thuo, P.K., Abdelfettah, Y., Schuster, M., Bourquin, S., Bellon, H., Clément, J.P., Guillou, H., Nalpas, T., Ruffet, G., 2012. Stratigraphy, sedimentology and diagenetic evolution of the Lapur Sandstone in northern Kenya: Implications for oil exploration of the Meso-Cenozoic Turkana depression. J. African Earth Sci. 71-72, 43-79. doi:10.1016/j.jafrearsci.2012.06.007

Turner, P., 1973. The stratigraphy and sedimentology of the Ringerike Group of Norway. University of Leicester.

Upcott, N.M., Mukasa, R.K., Ebinger, C.J., 1996. Along-axis segmentation and isostasy in the Western rift, East Africa. J. Geophys. Res. 101, 3247-3268.

Vail, P.R., Mitchum, R.M., Thompson, S.I., 1977. Seismic stratigraphy and global changes of sea level: Part 3, Relative changes of sea level from coastal onlap, in: Seismic Stratigraphy Applications to Hydrocarbon Exploration. American Association of Petroleum Geologists, Exxon Prod. Res. Co., Houston, Tex., United States, pp. 63-81.

Van Damme, D., Pickford, M., 2003. The late Cenozoic Thiaridae (Mollusca, Gastropoda, Cerithioidea) of the Albertine Rift Valley (Uganda-Congo) and their bearing on the origin and evolution of the Tanganyikan thalassoid malacofauna. Hydrobiologia 498, 1-83.

Van Damme, D., Pickford, M., 1994. The Late Cenozoic freshwater molluscs of the Albertine Rift, Uganda-Zaire: evolutionary and palaeoecological implications. Geol. Palaeobiology Albertine Rift Val. Uganda-Zaire 2, 71-87.

van der Beek, P., Mbede, E., Andriessen, P., Delvaux, D., 1998. Denudation history of the Malawi and Rukwa Rift flanks (East African Rift System) from apatite fission track thermochronology. J. African Earth Sci. 26, 363-385. doi:10.1016/S0899-5362(98)00021-9

Van Wagoner, J.C., Mitchum, R.M., Campion, K.M., Rahmanian, V.D., 1990. Siliciclastic sequence stratigraphy in well logs, cores, and outcrops: concepts for high-resolution correlation of time and facies. American Association of Petroleum Geologists Methods in Exploration Series.

Van Wagoner, J.C., Posamentier, H.W., Mitchum, R.M., Vail, P.R., Sarg, J.F., Louti, T.S., Hardenbold, J., 1988. An overview of the fundamentals of sequence stratigraphy and key definitions, in: Wilgus, C.K., Posamentier, H.W., Ross, C.K., Kendall, C.G. (Eds.), Sea Level Changes: An Integrated Approach. Society for Sedimentary Geology Special Publication, pp. 39-45.

Wallner, H., Schmeling, H., 2016. Numerical models of mantle lithosphere weakening, erosion and delamination induced by melt extraction and emplacement. Int. J. Earth Sci. 105, 1740-1760.

Wallner, H., Schmeling, H., 2010. Rift induced delamination of mantle lithosphere and crustal uplift: a new mechanism for explaining Rwenzori Mountains' extreme elevation? Int. J. Earth Sci. 99, 1511-1524. doi:10.1007/s00531-010-0521-6

Watts, A.B., Steckler, M.S., 1979. Subsidence and eustasy at the continental margin of eastern North America. Deep Drill. Results Atl. Ocean Cont. Margins Paleoenviron. 218-234.

Wayland, E.J., 1926. The Geology and palaeontology of the Kaiso bone-beds. Geological Survey of Uganda.

Wells, J.T., Scholz, C.A., Soreghan, M.J., 1999. Processes of sedimentation on a lacustrine borderfault margin: interpretation of cores from Lake Malawi, East Africa. J. Sediment. Res. 69, 816831.

Wescott, W.A., Krebs, W.N., Engelhardt, D.W., Cunningham, S.M., 1991. New Biostratigraphic Age 
Dates from the Lake Rukwa Rift Basin in Western Tanzania: Geologic Note (1). Am. Assoc. Pet. Geol. Bull. 75, 1255-1263.

Wheeler, W.H., Karson, J.A., 1994. Extension and subsidence adjacent to a "weak" continental transform: An example from the Rukwa rift, East Africa. Geology 22, 625-628.

Williams, A.J.W., Adamson, D., Prescott, J.R., Williams, F.M., 2003. New light on the age of the White Nile. Geol. Soc. Am. 31, 1001-1004.

Wölbern, I., Rümpker, G., Schumann, a., Muwanga, a., 2010. Crustal thinning beneath the Rwenzori region, Albertine rift, Uganda, from receiver-function analysis. Int. J. Earth Sci. 99, 1545-1557. doi:10.1007/s00531-009-0509-2

Yalden, D.W., 2011. Cenozoic Mammals of Africa. Zool. J. Linn. Soc. 163, 1-316.

Yasui, K., Kunimatsu, Y., Kuga, N., Bajope, B., Ishida, H., 1992. Neogene strata in the Sinda basin, Estearn Zaire. African study Monogr. Suppl. issue. 17, 87-107.

Zanettin, B., Justin Visentin, E., Bellieni, G., Piccirillo, E.M., Rita, F., 1983. Le volcanisme du Bassin du Nord-Turkana (Kenya): Age, succession et évolution structurale. Bull. des Centres Rech. Explor. Elf-Aquitaine 7, 249-255. 


\section{FIGURE 1: (2 columns fitting image)}

Figure 1: The East African Rift System and its western branch. Morphological and Cenozoic geological settings of the East African Rift System (Fig. 1a) and geological features of the western branch from the Archean (cratons) to Mesozoic (Karoo basins) and Cenozoic (East African rifts) (Fig. 1b). Faults and geological contours from Chorowicz (2005), Le Gall et al. (2000, 2004, 2005), McCarthy (2005) and the Tectonic map of Africa, Milesi et al. (2010).
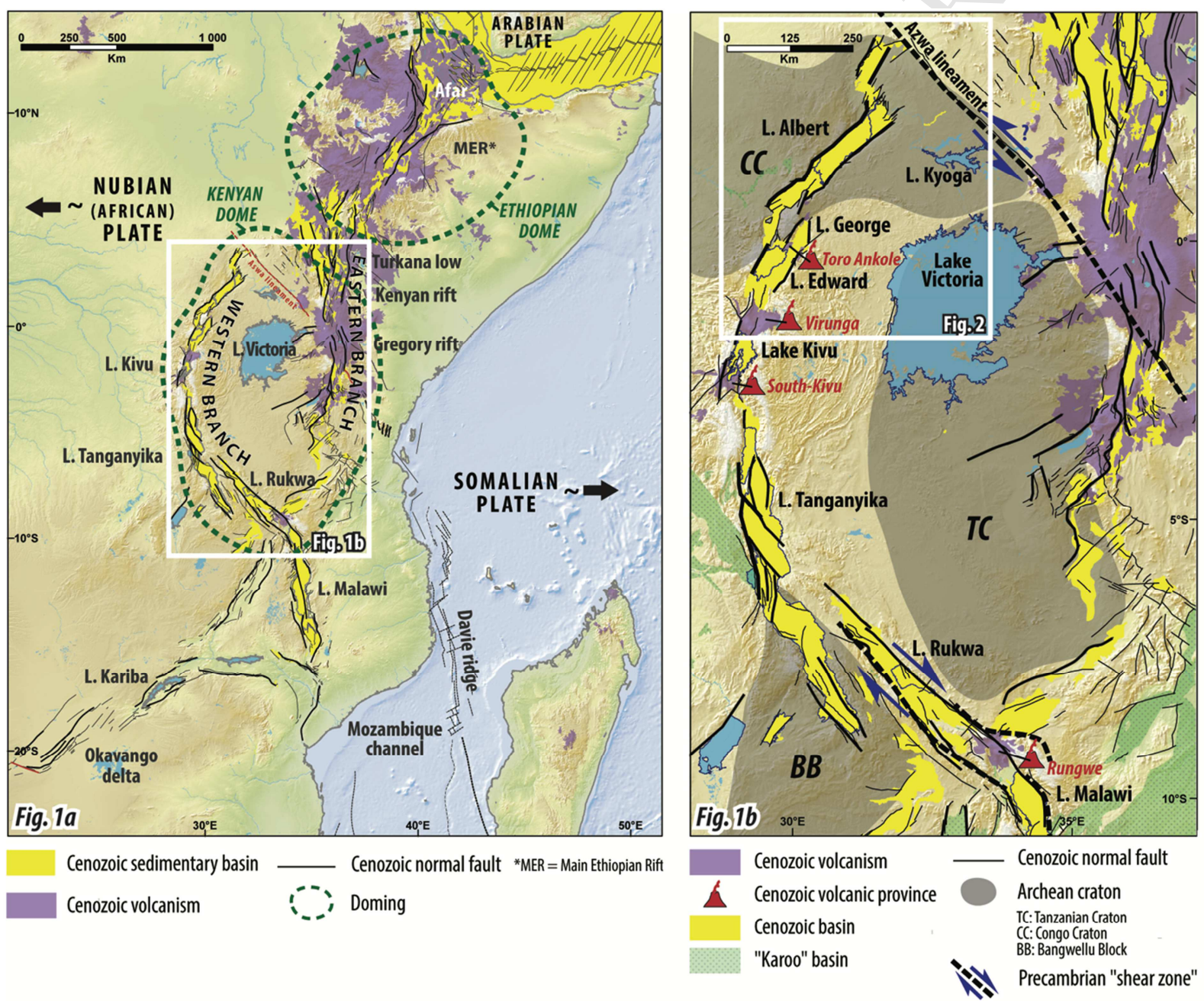


\section{FIGURE 2: (2 columns fitting image)}

Figure 2: The Albertine Rift System. Geological and structural map of the Albertine Rift

system from the Azwa lineament to the Virunga volcanic province. Geological contours, faults and structural lineaments modified after MacDonald and the Department of Geological Survey and Mines of Uganda, 1966 and GTK Consorsium, Jenett et al. (2009).

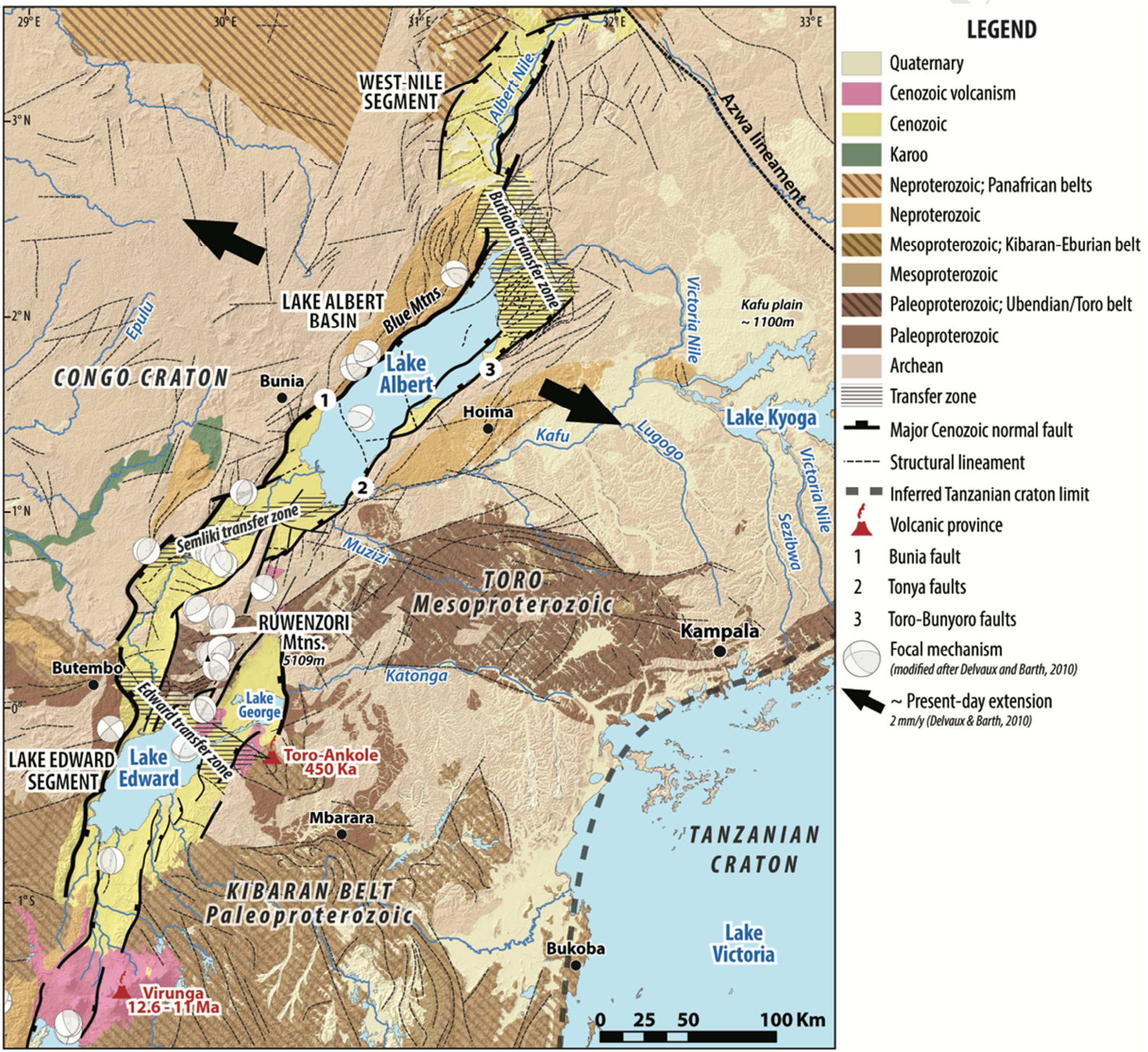




\section{FIGURE 3: (1.5 column fitting image)}

Figure 3: Location map of the interpreted data. The wells and field-sections are localized onshore on the Ugandan side of the Lake Albert Basin. Wells 1 to 5 correspond to petroleum exploration wells while wells $A$ and $B$ are fictive wells interpreted from the seismic data.

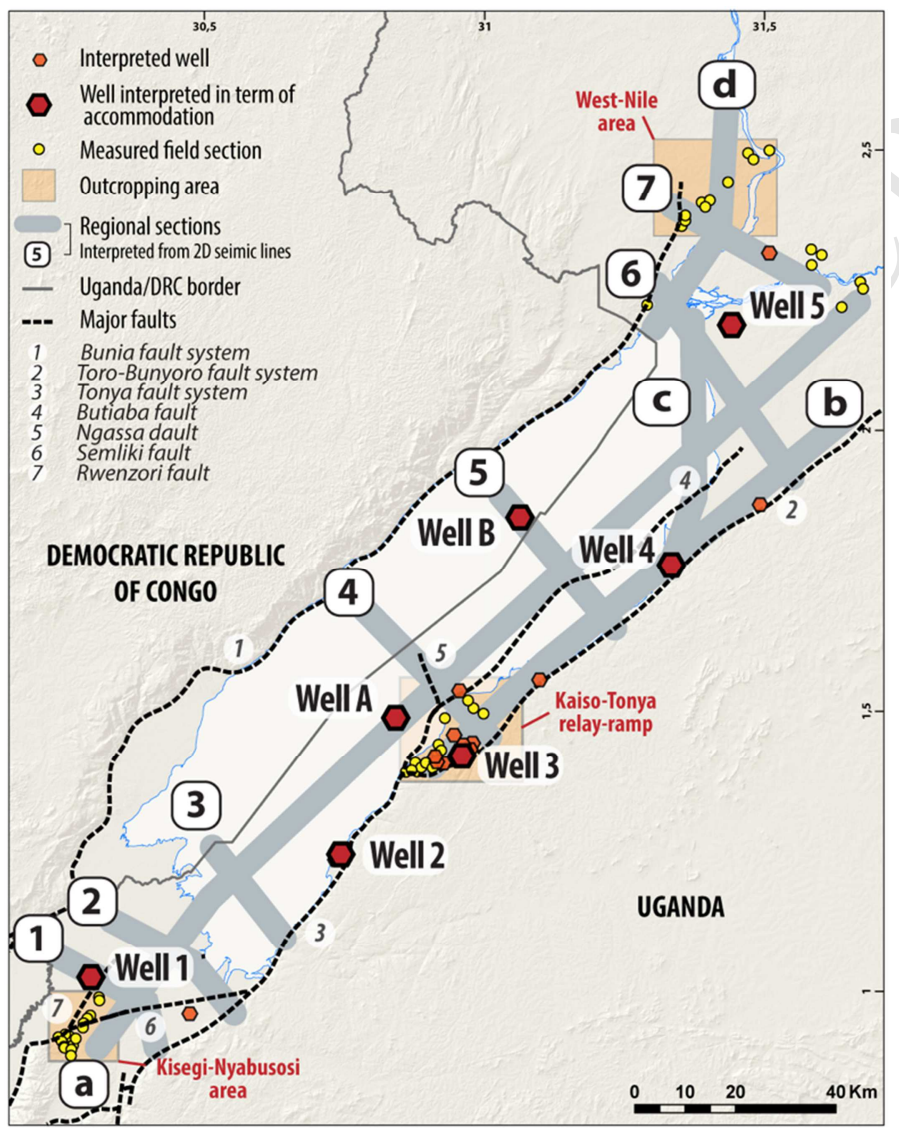




\section{FIGURE 4: (2 columns fitting image)}

Figure 4: Main characteristics of the litho-facies associations. Main depositional environments, lithologies, palynomorph and well-log signatures of the five facies associations identified on the outcrops and wells.

FACIES ASSOCIATION 1 (Fa1): Distal "deep" lacustrine

0 Gamma-Ray $200 \quad 0.75$ Porosity 0.15

\begin{tabular}{|c|c|c|c|c|}
\hline Lithology and granulometry & Sedimentary structures & $\begin{array}{c}\text { Bioturbation \& } \\
\text { biological content }\end{array}$ & $\begin{array}{c}\text { Process of formation } \\
\text { Interpretation }\end{array}$ & Well-logs facies signature \\
\hline $\begin{array}{l}\text { Homolithic and massive or } \\
\text { horizontally laminated dark to light } \\
\text { grey clays }\end{array}$ & $\begin{array}{l}\text { Few ferrugineous nodules and concretions; } \\
\text { diagenetic gypsum }\end{array}$ & $\begin{array}{l}\text { - Botryococcus algae } \\
\text { - Rare in-situ freshwater bivaves } \\
\text { - Organic-rich (carbonaceous) }\end{array}$ & $\begin{array}{l}\text { - Decantation } \\
\text { - Distal lake }\end{array}$ & 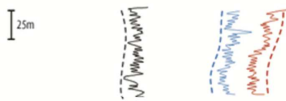 \\
\hline
\end{tabular}

Cylindrical and homolithic to slightly silty heterolithic facies; high radioactivity (clays)

FACIES ASSOCIATION 2 (Fa2): Proximal "shallow" lacustrine

\begin{tabular}{|c|c|c|c|c|}
\hline Lithology and granulometry & Sedimentary structures & $\begin{array}{c}\text { Bioturbation \& } \\
\text { biological content }\end{array}$ & $\begin{array}{l}\text { Process of formation } \\
\text { Interpretation }\end{array}$ & Well-logs facies signature \\
\hline $\begin{array}{l}\text { - Alternation of grey clays, silty clays } \\
\text { and thin beds }(1-20 \mathrm{~cm}) \text { of fine to } \\
\text { medium sands } \\
\text { - Poorly sorted sands }\end{array}$ & $\begin{array}{l}\text { - Clays: massive or horizontally laminated } \\
\text { - Sands: most of the time massive; rare } \\
\text { unidirectional current ripples or megaripples } \\
\text { cross-bedding, horizontal bedding }\end{array}$ & $\begin{array}{l}\text { - Occasional vertical and/or horizontal } \\
\text { burrows in sand } \\
\text { - Most of the time monospecific; rare beds } \\
\text { showing plurispecific bioturbations }\end{array}$ & $\begin{array}{l}\text { - Decantation perturbated } \\
\text { by floods } \\
\text { - Shallow lake }\end{array}$ & 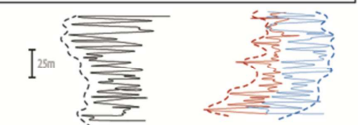 \\
\hline - Clay dominated & & $\begin{array}{l}\text { - Pediastrum algae } \\
\text { - Locally organic-rich }\end{array}$ & & $\begin{array}{l}\text { High variations (thin peaks) of radioactivity } \\
\text { (gamma-ray) and porosity values. Funnel shape } \\
\text { of gamma-ray (coarsening upward trend) }\end{array}$ \\
\hline
\end{tabular}

\begin{tabular}{|c|c|c|c|c|}
\hline Lithology and granulometry & Sedimentary structures & $\begin{array}{c}\text { Bioturbation \& } \\
\text { biological content }\end{array}$ & $\begin{array}{l}\text { Process of formation } \\
\text { Interpretation }\end{array}$ & Well-logs facies signature \\
\hline $\begin{array}{l}\text { - Fine- to coarse-grained } \\
\text { sandstones; predominantly } \\
\text { medium- grained (decimetric to } \\
\text { plurimetric beds; } 20 \mathrm{~cm}-2-3 \mathrm{~m} \text { ) } \\
\text { - Well sorted, occasional coarsening } \\
\text { upward trend }\end{array}$ & $\begin{array}{l}\text { (a) Current ripple and megaripple (3D) } \\
\text { cross-bedding; decimetric set; localized } \\
\text { reactivation surfaces and interbedded clays } \\
\text { (b) Climbing ripple and megaripple and 3D/2D } \\
\text { megaripples cross-bedding surimposed on sand } \\
\text { bars -> (compound cross-bedding); } \\
\text { (a) and (b): top of bed-set locally consisting of } \\
\text { by-passing surface (peeble level) }\end{array}$ & $\begin{array}{l}\text { - Occasional monospecific bioturbation } \\
\text { (vertical burrows) } \\
\text { - Pediastrum algae in clayey interval }\end{array}$ & $\begin{array}{l}\text { - Lacustrine delta: } \\
\text { subaquatic distal } \\
\text { mouth-bars }\end{array}$ & Funnel shapes (coarsening up trend); sandy \\
\hline
\end{tabular}

FACIES ASSOCIATION 4(Fa4): Lacustrine shoreline

\begin{tabular}{|l|l|l|l|l|}
\hline Lithology and granulometry & \multicolumn{1}{|c|}{ Sedimentary structures } & \multicolumn{1}{c|}{$\begin{array}{c}\text { Bioturbation \& } \\
\text { biological content }\end{array}$} & $\begin{array}{c}\text { Process of formation } \\
\text { Interpretation }\end{array}$ & Well-logs facies signature \\
\hline $\begin{array}{l}\text { - Massive fine- to medium-grained } \\
\text { clean and well sorted sandstone } \\
\text { (decimetric to metric beds) }\end{array}$ & -Current and avalanching ripple/megaripple & - - cross-bedding bioturbated; horizontal and vertical & - Lacustrine shoreline & Similar to Fa2 electro-facie due to numerous \\
burrows, plurispecific bioturbation & - Lacustrine embayment & interstratifations of clayey intervals (Fa1) \\
\hline
\end{tabular}

FACIES ASSOCIATION 5 (Fa5): Lacustrine coastal plain

\begin{tabular}{|c|c|c|c|c|}
\hline Lithology and granulometry & Sedimentary structures & $\begin{array}{c}\text { Bioturbation \& } \\
\text { biological content }\end{array}$ & $\begin{array}{c}\text { Process of formation } \\
\text { Interpretation }\end{array}$ & Well-logs facies signature \\
\hline $\begin{array}{l}\text { - Dark-grey to green massive clays, } \\
\text { locally silty } \\
\text { - Few hydromorphic soil }\end{array}$ & None & $\begin{array}{l}\text { - Rare burrows (insect?) } \\
\text { - Plant remains, lignite (cuticles, wood } \\
\text { debris) } \\
\text { - Poaceae, graminae }\end{array}$ & $\begin{array}{l}\text { - Decantation } \\
\text { - Lacustrine coastal plain: } \\
\text { marshes, ponds } \\
\text { - Water saturation }\end{array}$ & $\begin{array}{l}\text { Ism } \\
\text { Bell and cylindrical shape; low density, high } \\
\text { porosity and radioactivity (lignite and clays }\end{array}$ \\
\hline
\end{tabular}

FACIES ASSOCIATION 6 (Fa6): River channel

\begin{tabular}{|c|c|c|c|c|}
\hline Lithology and granulometry & Sedimentary structures & $\begin{array}{c}\text { Bioturbation \& } \\
\text { biological content }\end{array}$ & $\begin{array}{c}\text { Process of formation } \\
\text { Interpretation }\end{array}$ & Well-logs facies signature \\
\hline $\begin{array}{l}\text {-Very coarse- to medium-grained } \\
\text { reddish sandstones (decimetric to } \\
\text { plurimetric beds) } \\
\text { - Relatively well sorted; fining }\end{array}$ & $\begin{array}{l}\text { - Megaripples (2D) cross-bedding in decimetric } \\
\text { laminasets } \\
\text { - Sharp end/or erosional base } \\
\text { - Occasional basal conglomeratic lag }\end{array}$ & Rare burrows (insect?) & $\begin{array}{l}\text { - Bedload } \\
\text { - Distributary channel of a } \\
\text { lacustrine delta } \\
\text { - Alluvial plain }\end{array}$ & Bell shape with sharp base (fining -up \\
\hline
\end{tabular}




\section{FIGURE 5: ( 2 columns fitting image, landscape orientation)}

Figure 5: Basin-scale correlations. Examples of correlated wells along the Lake Albert Basin.

Correlations were performed with respect to the sequence stratigraphy method and paleoenvironmental data (palynomorph, example in Figure 6 for well 1). The locations of the wells and outcrops are given in Figure 3. 


\section{Correlated surfaces}

un Unconformity (Un)

-.. Maximum flooding surface (MFS)

- Maximum regressive surface (MRS)

Transgressive half-cycle

$\nabla$ Regressive half-cycle

\section{Lithology}

$\square$ Sand
$\square$ Heterolithic - sandy dominated
$\square$ Heterolithic - clayey dominated

Clay

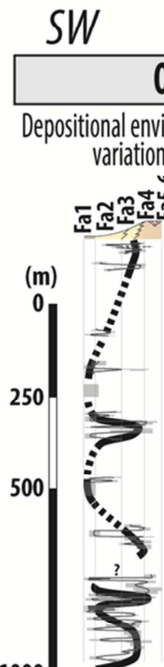

OUTCROPS (Kisegi-Nyabusosi irea)

a1: Distal «deep» lacustrine $\mathrm{m:m}$

Fa2: Proximal "shallow» lacustrine $\mathbf{r}: \mathbf{m r}$

4: Lacustrine shoreline and embayment

a5: Lacustrine coastal plain
Fa6: River chanel

C4 ? mm? S4Un?

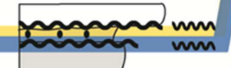

S4Un1

S4m mir mo

'S3m

. $22 r$

$\cdots \frac{\mathrm{S} 2 \mathrm{~m}}{\mathrm{~S} 1 \mathrm{r}}$

S1Un

n)

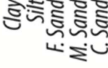
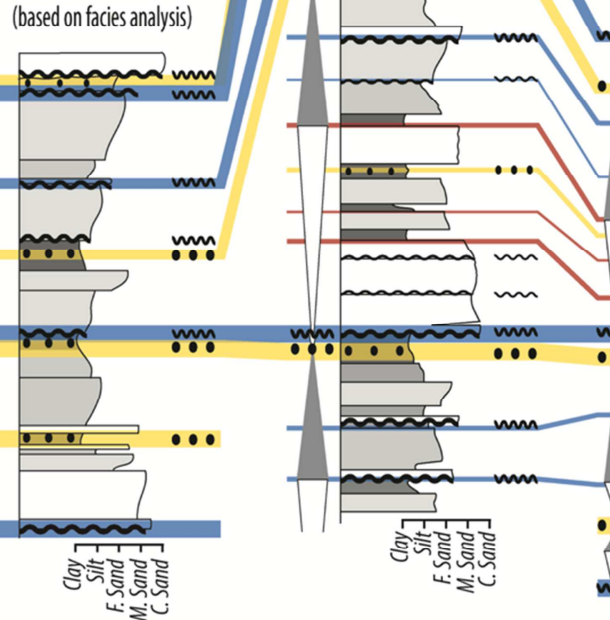

\section{WELL 2}

Schematic log

(based on GR, Neutron-Density

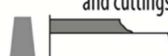

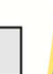

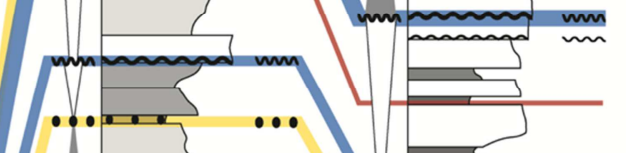

0.0 .0 ?

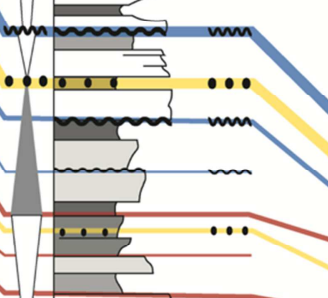

\section{WELL 3}

Schematic log (based on GR, Neutron-Density and cuttings)

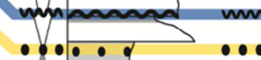
- ond curns
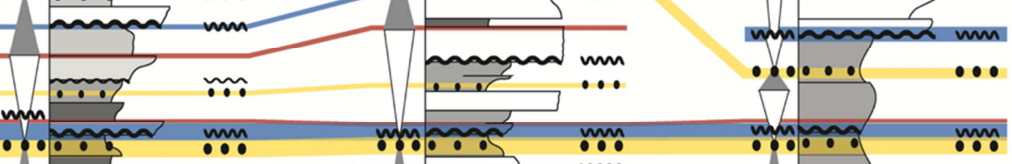

min

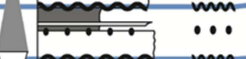

...

$\ldots$

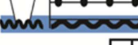

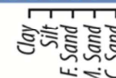

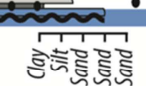

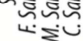

$\ldots \ldots$

NE

WELL5

Schematic log (based on GR, Neutron-Density and cuttings)

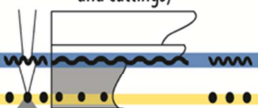

(1)

.0 .0 .075 ma

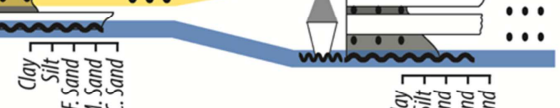

츤ํํำํํำ 


\section{FIGURE 6: ( 2 columns fitting image, landscape orientation)}

Figure 6: Age model of the Lake Albert Basin sedimentary infilling. Ages of the seven stratigraphic surfaces interpreted from field and subsurface analyses. The biostratigraphic ages are compared to the paleo-environmental (palynomorph; Total, pers. comm.) and regional climatic chart (Bonnefille, 2010). 

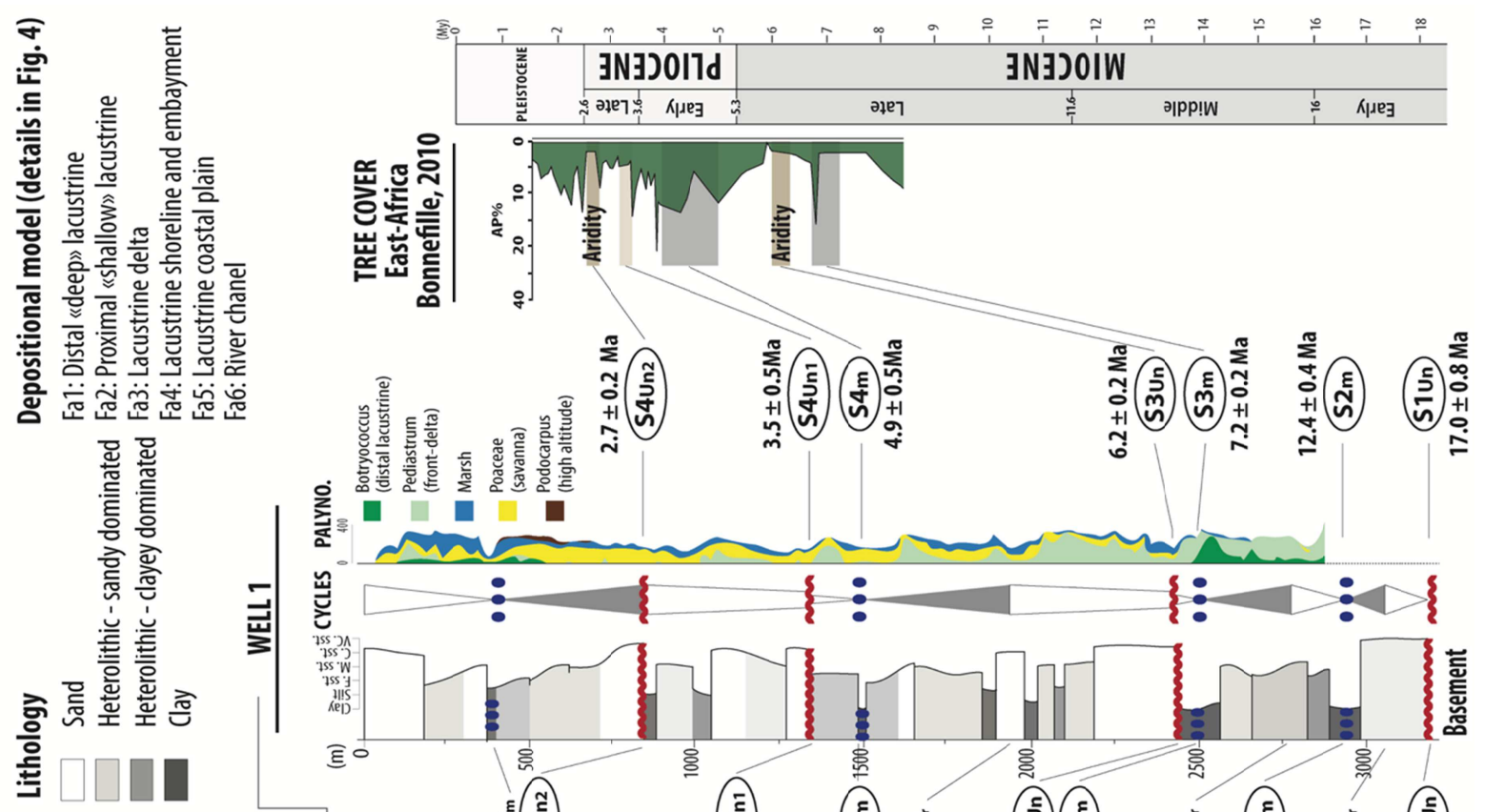

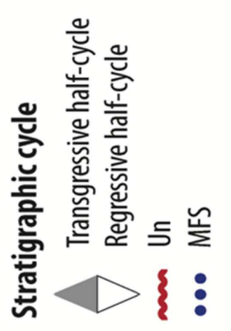
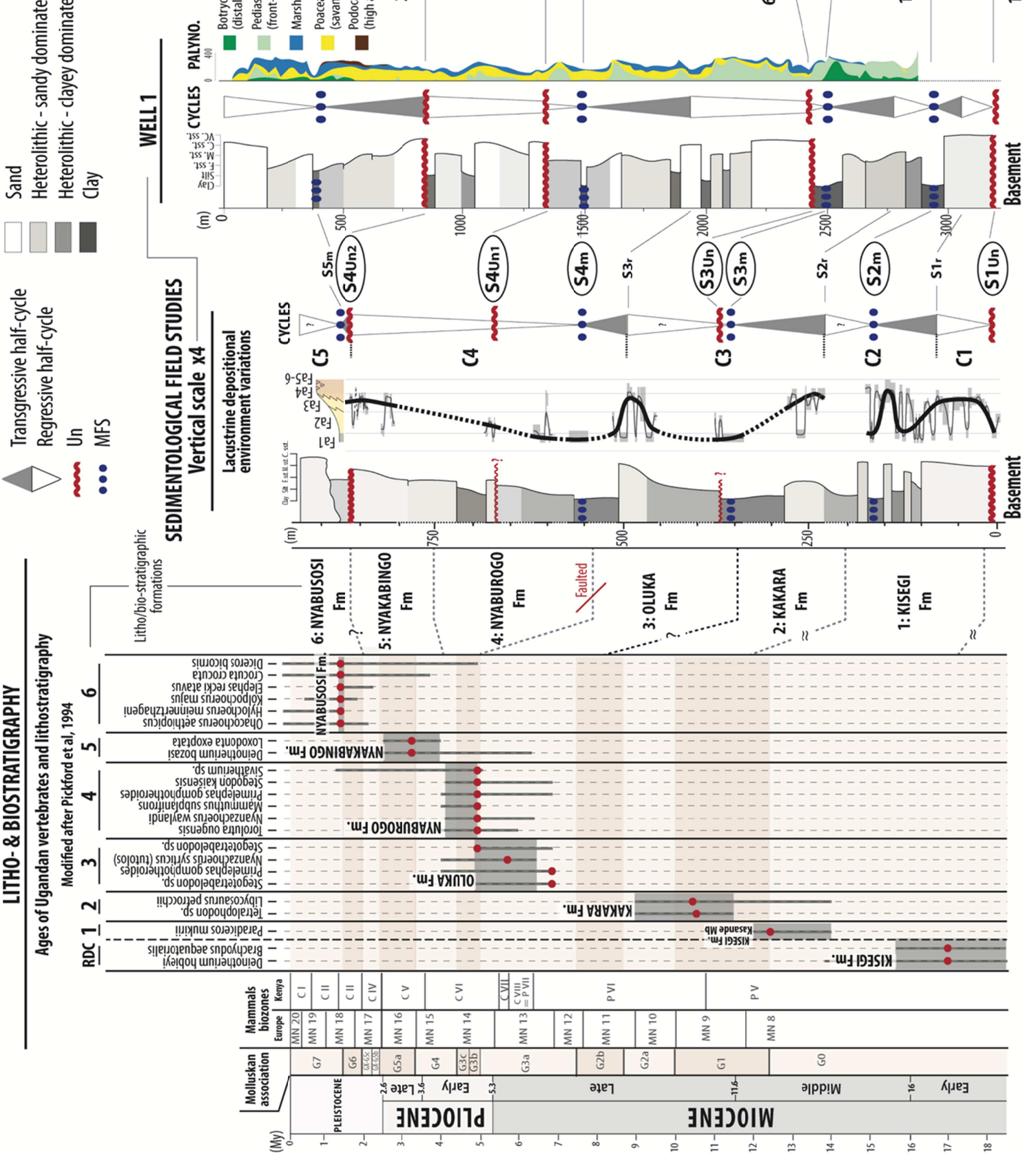


\section{FIGURE 7: (2 columns fitting image)}

Figure 7: Accommodation and associated accommodation rate evolution of the Lake Albert

Basin. The accommodation is measured using the backstripping method on five exploration wells (wells 1 to 5 ) and two fictive wells (wells $A$ and B) interpreted from the seismic data. See Figure 3 for the location of the wells.
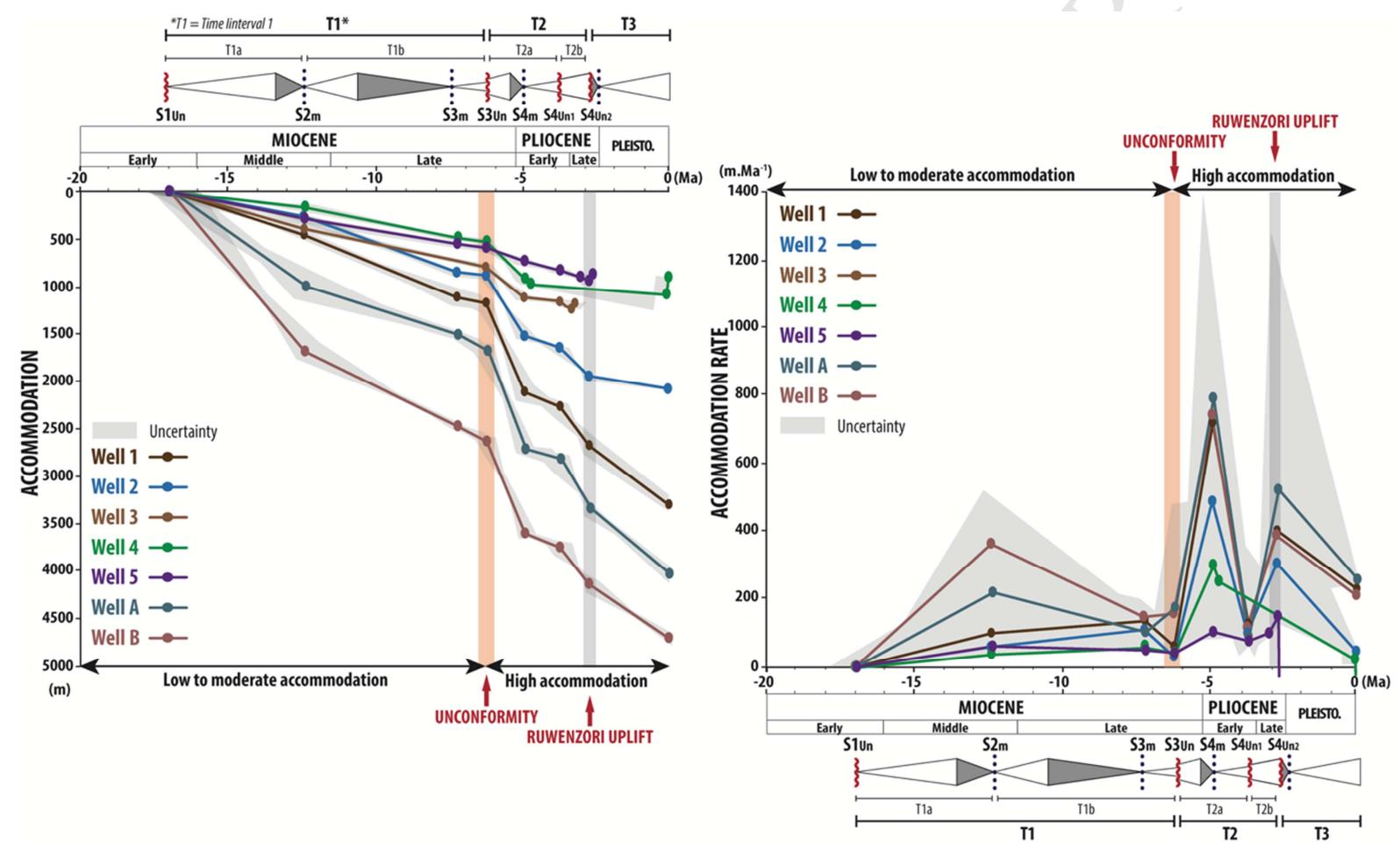


\section{FIGURE 8: ( 2 columns fitting image)}

Figure 8: Isopach and sedimentation rate maps of the Lake Albert Basin. Compilation of thickness (isopach) and sedimentation rate maps for three time intervals (T1, T2, T3). 
TIME INTERVAL 1: $17.0 \pm 0.8 \mathrm{Ma}$ (S1Un) $-6.2 \pm 0.2 \mathrm{Ma}$ (S3Un)
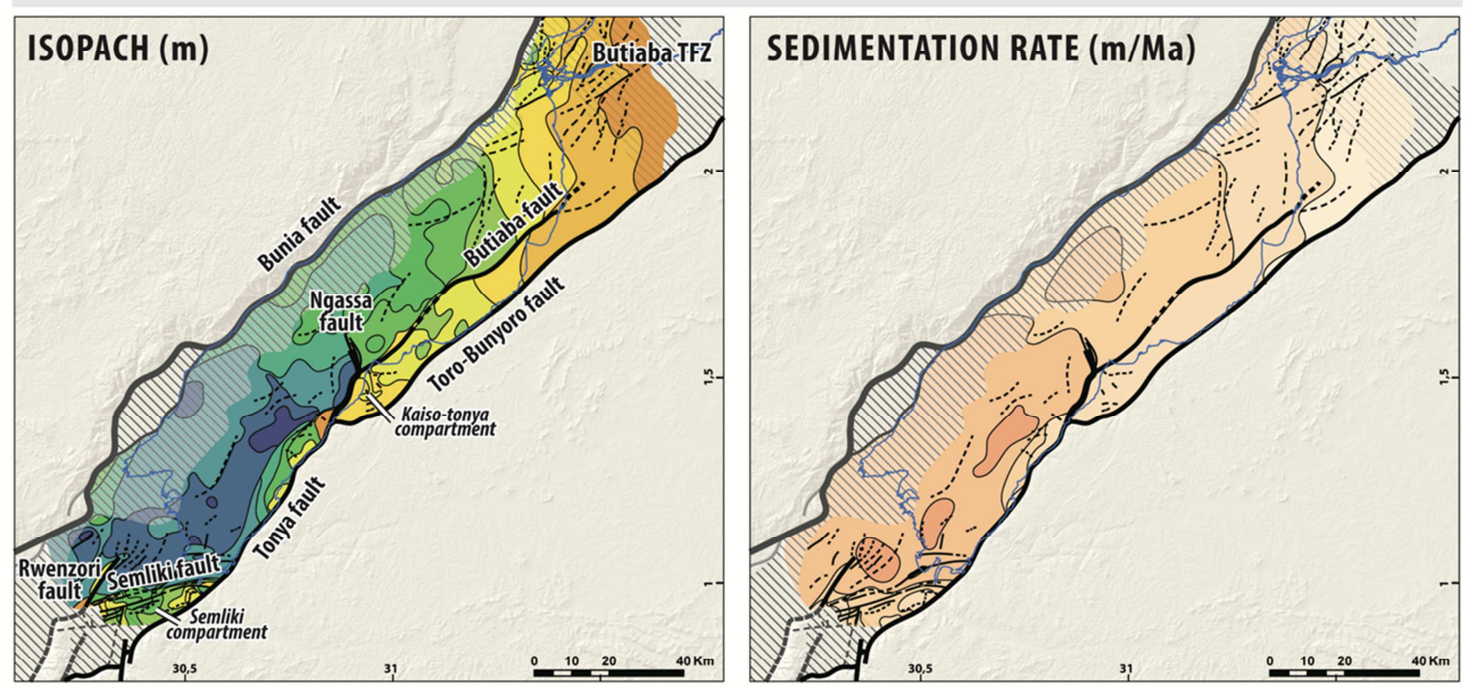

TIME INTERVAL 2: $6.2 \pm 0.2 \mathrm{Ma}$ (S3Un) - $2.7 \pm 0.2 \mathrm{Ma}$ (S4Un2)
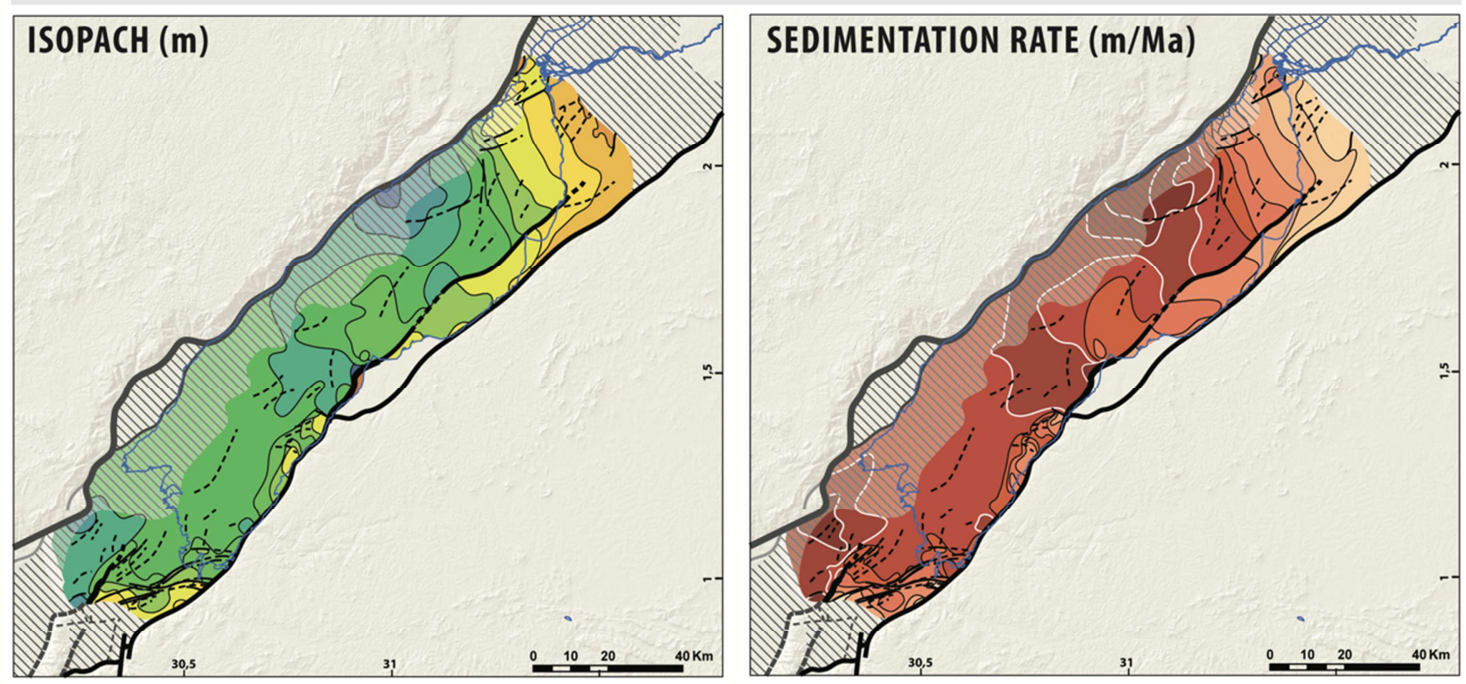

TIME INTERVAL 3: $2.7 \pm 0.1 \mathrm{Ma}$ (S4Un2) - Present Day

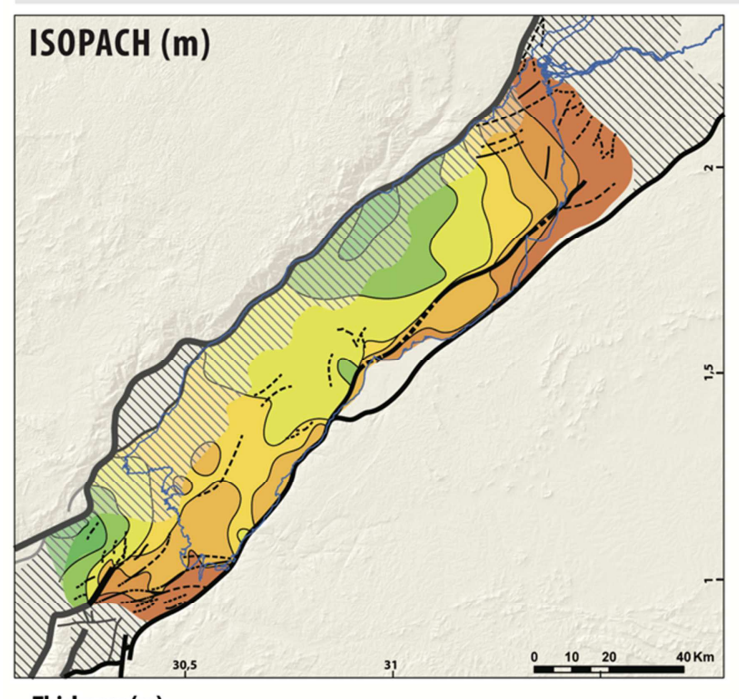

Thickness (m)

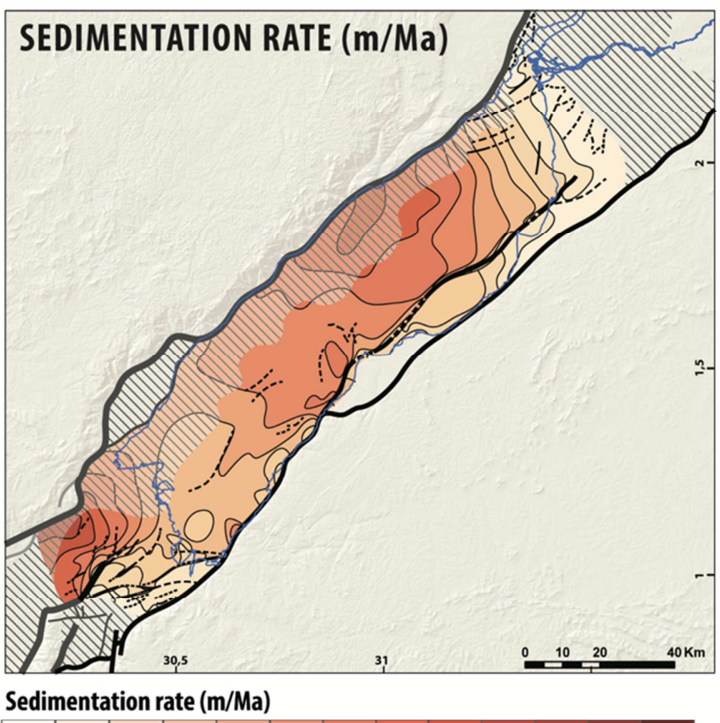

020040060080010001200140016001800200024002600 o $50 \quad 100150200250300350400450500550600800$ Present Lake Albert itlll' No data available or extrapolated data
shoreline 


\section{FIGURE 9: (2 columns fitting image; 9b :landscape} orientation)

Figure 9: Regional sections. Transverse (Fig. 9a) and longitudinal (Fig. 9b) regional sections of the Lake Albert Basin based on the interpretation of the 2D seismic lines. See Figure 3 for the location of the sections. 


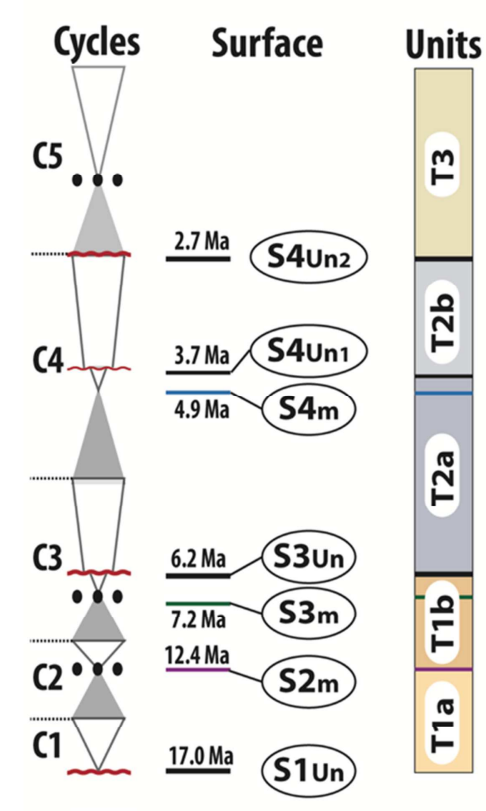

Paleo-structures

(older than Uppermost Early Miocene)

Fault throw $>300 \mathrm{~m}$

$300 \mathrm{~m}>$ Fault throw $>100 \mathrm{~m}$

Fault throw $<100 \mathrm{~m}$

Transgressive half-cycle

Regressive half-cycle

•.. MFS

m Un

\section{TRANSVERSE SECTIONS (NW-SE)}
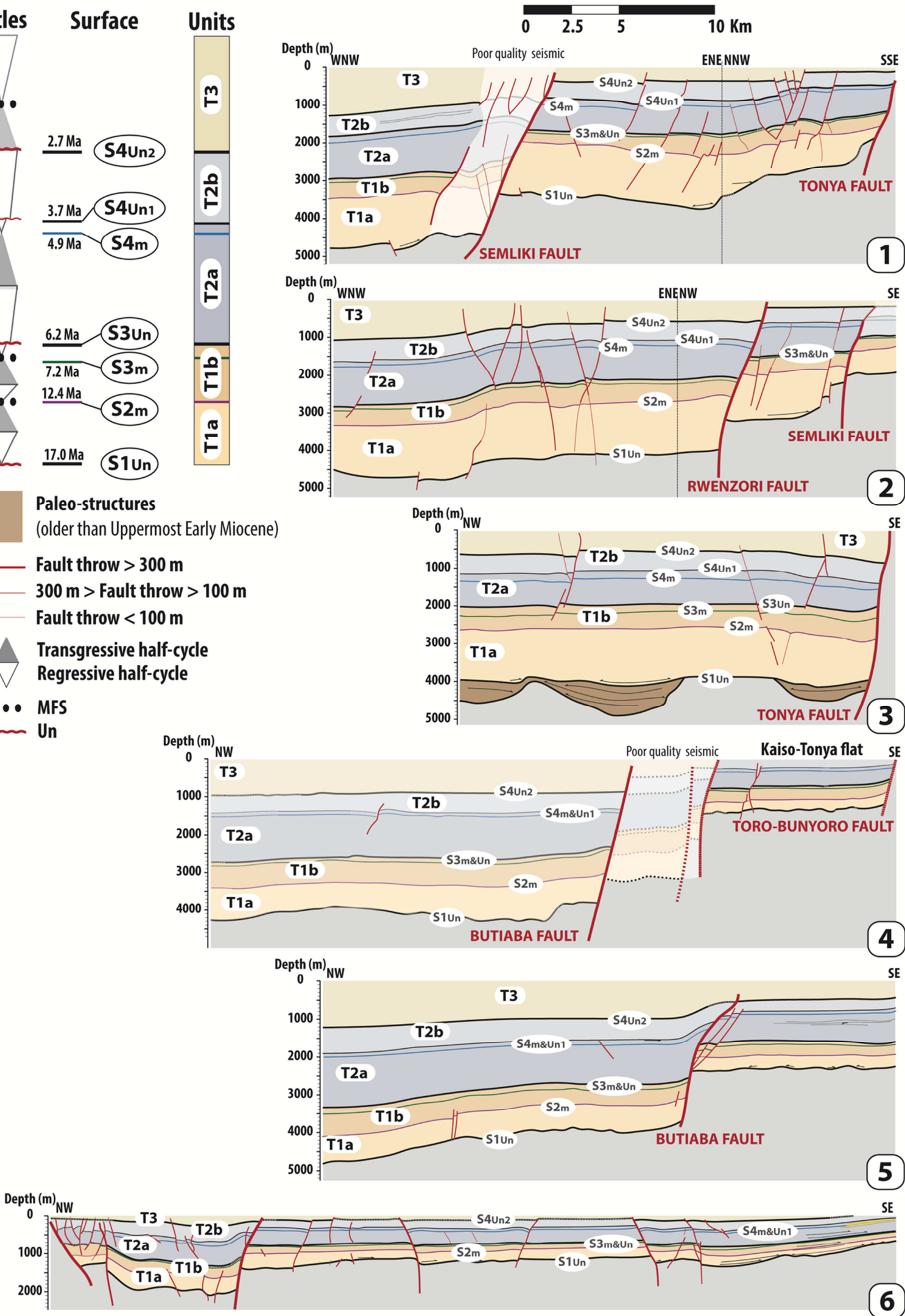

Fig. 9a

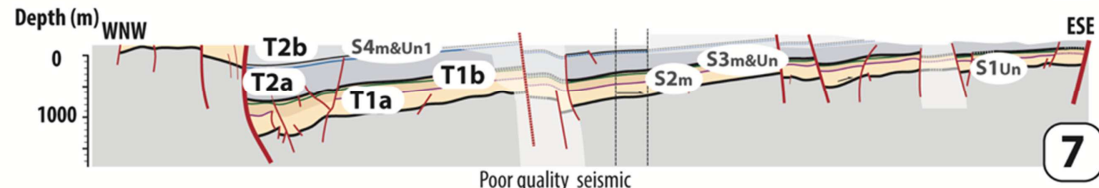




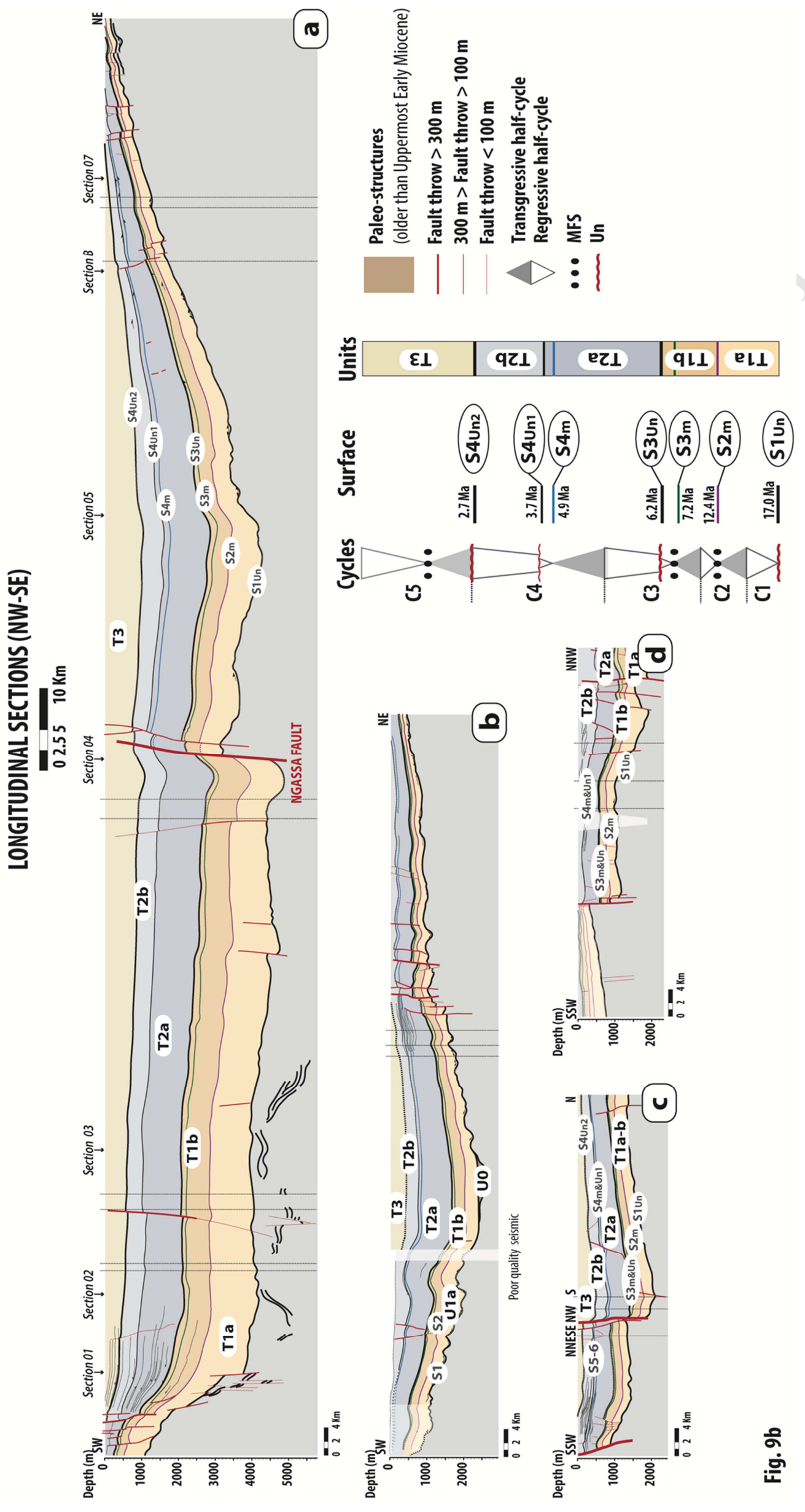




\section{FIGURE 10: (2 columns fitting image; landscape} orientation)

Figure 10: Synthetic chart of the Lake Albert Basin evolution. Climatic chart from Bonnefille

(2010) and ages of the volcanic episodes in the western branch from Ppuclet el al. (2016) and Kampunzu et al. (1998; and literature therein). 

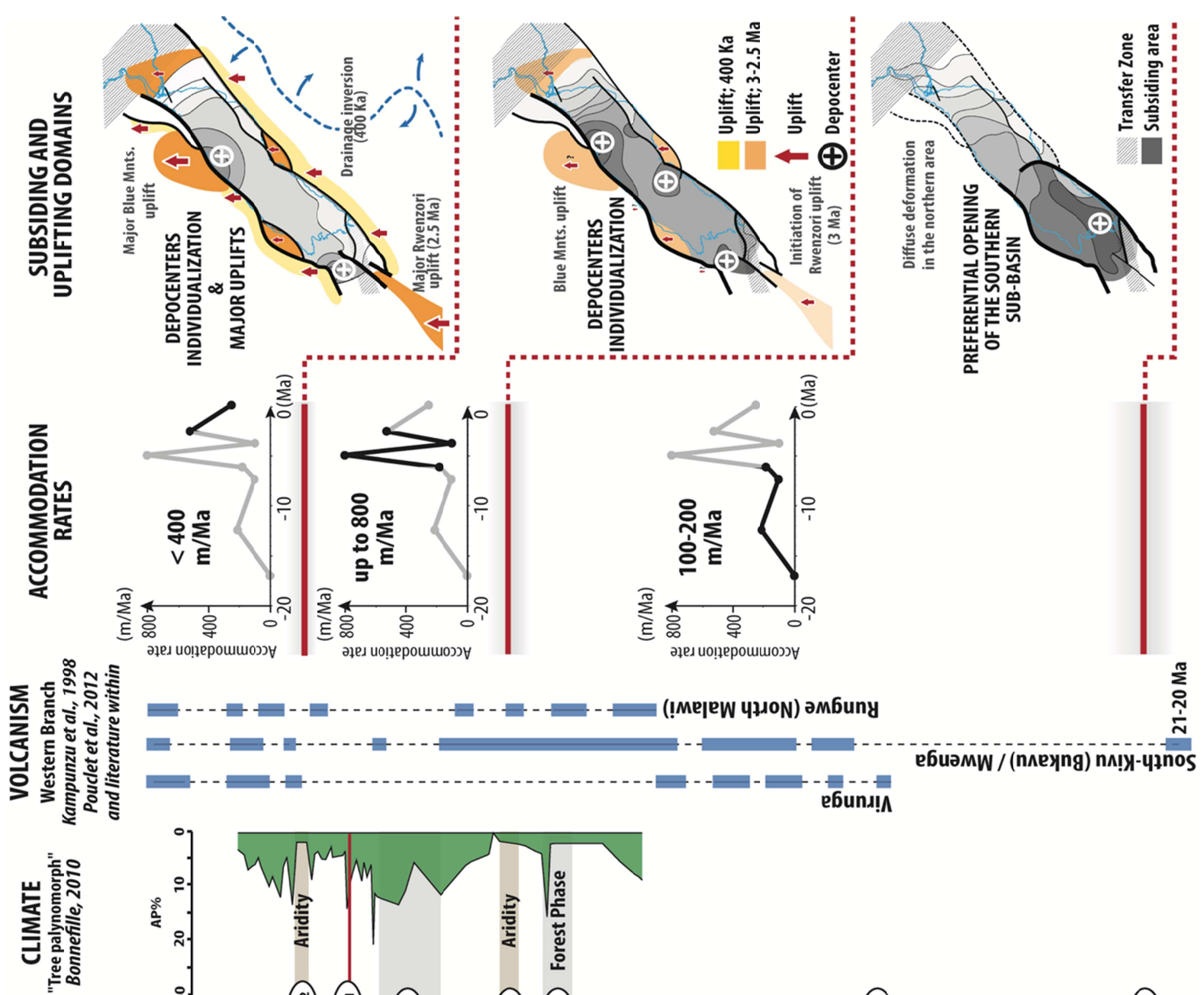

?.].

席岂总

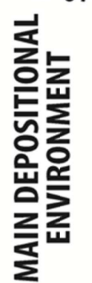

of
ผิ
(气)

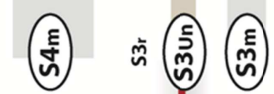
สั
(⿹气⿱幺⿲丶丶丶
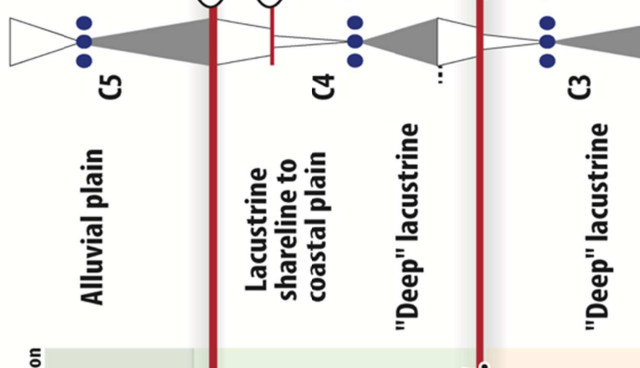

흘

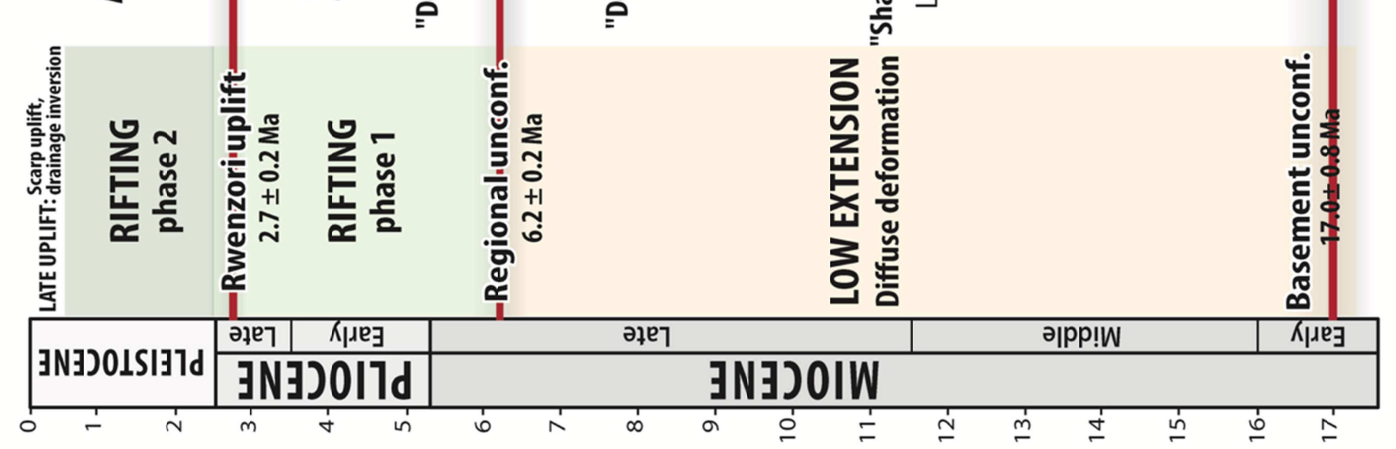




\section{FIGURE 11: (2 columns fitting image; landscape orientation)}

Figure 11: Synthetic chart of the initiation and main stages of evolution of the rift basins of the western and eastern branches of the East-African Rift System based on the age of their sedimentary and volcanic infilling (based on a bibliographic synthesis, references in the figure). 


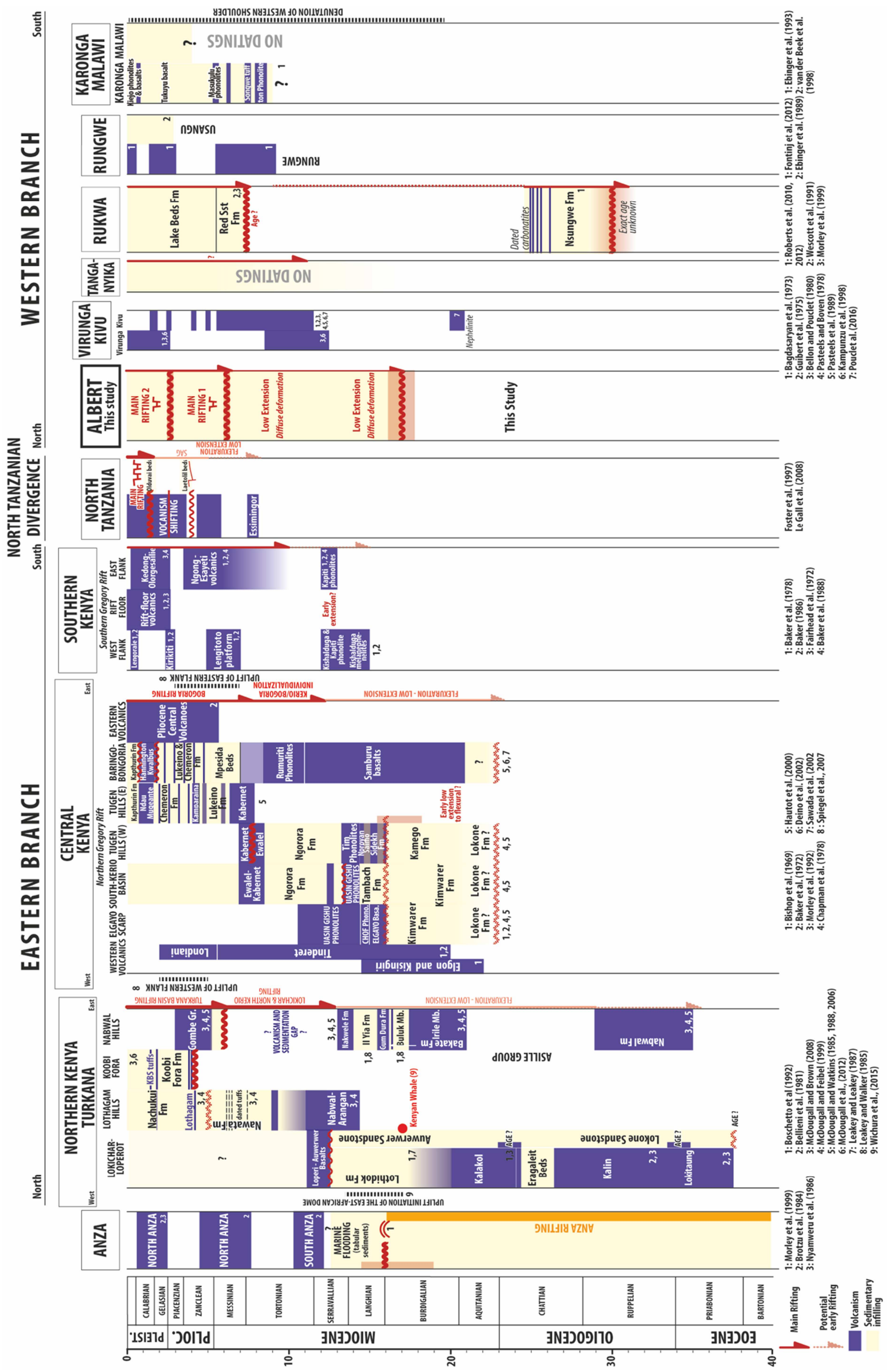




\section{RESEARCH HIGHLIGHTS}

- Early deposition in the Lake Albert Basin occurred during Early Miocene times (17 Ma), much older than the Late Miocene age previously mentioned.

- The sedimentary infilling essentially consists of sub-aquatic lacustrine deposits wherein major unconformities related to subsidence and climatic changes were characterized.

- The Lake Albert Rift evolution consists of three major steps: (1) low and diffuse extension from 17.0 to $6.2 \mathrm{Ma}$, (2) first phase of rifting from 6.2 to $2.5 \mathrm{Ma}$ and (4) second rifting phase and uplift of rift shoulder from 2.5 and $0 \mathrm{Ma}$. 